\title{
Fusarium Toxins in Cereals: Occurrence, Legislation, Factors Promoting the Appearance and Their Management
}

\author{
Davide Ferrigo ${ }^{\dagger}$, Alessandro Raiola ${ }^{\dagger}$ and Roberto Causin * \\ Department of Land, Environment, Agriculture and Forestry, University of Padua, Campus of Agripolis, \\ Viale Università 16, 35020 Legnaro, Padua, Italy; davide.ferrigo@unipd.it (D.F.); \\ alessandro.raiola@unipd.it (A.R.) \\ * Correspondence: roberto.causin@unipd.it; Tel.: +39-049-8272885 \\ + These authors contributed equally to this work. \\ Academic Editor: Derek J. McPhee \\ Received: 7 March 2016; Accepted: 9 May 2016; Published: 13 May 2016
}

\begin{abstract}
Fusarium diseases of small grain cereals and maize cause significant yield losses worldwide. Fusarium infections result in reduced grain yield and contamination with mycotoxins, some of which have a notable impact on human and animal health. Regulations on maximum limits have been established in various countries to protect consumers from the harmful effects of these mycotoxins. Several factors are involved in Fusarium disease and mycotoxin occurrence and among them environmental factors and the agronomic practices have been shown to deeply affect mycotoxin contamination in the field. In the present review particular emphasis will be placed on how environmental conditions and stress factors for the crops can affect Fusarium infection and mycotoxin production, with the aim to provide useful knowledge to develop strategies to prevent mycotoxin accumulation in cereals.
\end{abstract}

Keywords: Fusarium toxins; Fusarium disease; mycotoxin regulation; mycotoxin management

\section{Mycotoxigenic Fusarium and Fusarium-Related Diseases}

Fusarium is one of the most economically important genera of phytopathogenic fungi. Several Fusarium species can infect small grain cereals (wheat, barley and oat) and maize; the predominant species can vary according to crop species involved, geographic region and environmental conditions [1,2]. Fusarium toxins are secondary metabolites produced by toxigenic fungi that naturally contaminate cereals, they represent a source of grave concern in cereals and cereal-based products, resulting in harmful contamination of foods and feedstuffs [3].

Fusarium diseases that affect cereal crops are caused by several individual Fusarium or more commonly, co-occurring species. Fusarium spp. can cause indirect losses resulting from seedling blight or reduced seed germination, or direct losses such as seedling foot and stalk rots; however, the most important diseases in cereals due to a severe reduction in yield and quality are head blight of small cereals as wheat, barley and oat, and ear rot of maize [4,5]. The coexistence of different Fusarium spp. in the field is a normal situation and although the number of detectable species can be high [6], only some of them are pathogenic, especially under suitable climatic conditions. The composition of species involved in the Fusarium disease complex is dynamic [7]. The species comprising a Fusarium community associate with each other and this cohabitation is particularly affected by climatic factors such as temperature and moisture. Moreover, evidences indicates that the environmental conditions that favour the infection process can differ from those that affect colonization [8]; therefore, the relationship among Fusarium species may change over time during the infection process. 
Fusarium head blight (FHB) of small grain cereals is associated with up to 17 Fusarium species [9], but only a few of them are important worldwide in terms of diffusion and economic impact. Moreover, under cool and wet conditions, Microdochium nivale (syn. Fusarium nivale) represents an important co-occurring causal agent of FHB. The environmental conditions that promote FHB are moderate temperatures in the presence of high humidity. In addition, FHB is favoured by rainfall during and after flowering. The two main species responsible for FHB are Fusarium graminearum, a dominant species in warm and wet conditions, and Fusarium poae, which occurs under relatively warm and dry conditions [10,11]. F. graminearum, along with at least 16 different species belonging to the F. graminearum complex (FGC) [12], is the most prevalent and aggressive causal agent of FHB on both wheat and barley worldwide [13,14]. F. graminearum is prevalent in southern Europe [15], America [16] and Asia [17], however, it has been found to spread toward the cooler regions of Europe: Finland, Russia and Sweden [18,19]. Although F. poae has been previously considered a relatively low virulent pathogen of cereals compared with F. graminearum, recent studies identified this pathogen as the major FHB component of wheat in certain years or in different geographical areas [20]. The variability in the predominance of F. poae is highly influenced by the climate conditions of locations that are characterized by cold and moisture, where this fungus presents a high frequency but a lower density compared with warmer areas. This suggests the greater adaptability of F. poae under certain agro-environmental conditions where other Fusarium spp., such as F. graminearum, are less favoured. Other species such as F. avenaceum, F. culmorum, F. sporotrichioides and F. langsethiae are FHB agents considered to be of secondary importance; however, they can play significant roles in pathogenesis when climatic conditions are not favourable for the development of the main FHB causal agents [18,21,22].

In maize, Fusarium infection of the ear and kernels comprises two distinct diseases: Gibberella ear rot (GER) or "red ear rot" prevalently caused by species of the Discolor section, and Fusarium ear rot (FER) or "pink ear rot", mainly caused by species of the Liseola section [5]. Similar to FHB in wheat, Fusarium diseases in maize are characterized by the co-presence or rapid succession of different species; furthermore, GER and FER may be present on the ears at the same time. The prevalence of ear rot type varies according to the causal species, which mainly depends on the climatic parameters, the agronomic practices, the local composition of the fungal community and the susceptibility of the host plant. Fusarium diseases in maize are also influenced by insect activities that result in injured kernels. In fact, species belonging to the Liseola section are prevalent on ears damaged by corn borers whereas Fusarium belonging to Discolor section are well represented on maize ears that are not damaged by insects [23]. This behaviour appears to be particularly linked to the different ways in which Fusarium colonizes ears; in fact, F. verticillioides, which is characterized by low virulence, typically infects plants through injuries [24] and in lesser extent silks [25], while F. graminearum is highly virulent and can strongly infect plant tissues [26]. The predominant species causing GER are F. graminearum, F. culmorum and to a lesser extent, F. avenaceum, however, several other species such as F. equiseti, F. poae, F. sporotrichioides, F. acuminatum, F. semitectum, F. solani and F. temperatum can be isolated with lower frequency from molded maize ears. The dynamic of infection and fungal community involved in GER follow the same behaviour observed in FHB of small cereals and is favoured by high moisture at silking under warm conditions $[27,28]$.

The main Fusarium species involved in FER is F. verticillioides, with a $100 \%$ incidence under conducive conditions; however, also F. proliferatum and F. subglutinans are important causal agents. F. verticillioides is likely the most common species isolated worldwide from diseased maize [29]. Compared with GER, FER occurs under hotter and drier conditions, especially after pollination [30]. The predominance of F. verticillioides among Fusarium isolates has been observed in Europe [31,32], Africa [33], Asia [34] and America [35,36] over time, with a colonization incidence of up to $90 \%$. F. verticillioides is often associated with F. subglutinans, which occupies the same ecological niche and thus competes for nutrients and space. In addition, the incidence of F. proliferatum populations in southern maize-growing areas has been widely reported [37]. The dynamics of fungal communities involved in FER are strongly influenced by interactions with host and environmental factors, in 
fact $F$. subglutinans and F. proliferatum occur as moderately aggressive pathogens but are generally considered to require cooler temperatures than F. verticillioides [38], which is characterized by low pathogenicity $[39,40]$ but high adaptability to the hot conditions.

Although cereal fusariosis strongly affects crop production, several Fusarium spp. also produce a wide range of toxins that can reach concentrations harmful to humans and animals. The particular mycotoxin combination is species- $[41,42]$ and strain-specific $[43,44]$; moreover, the toxigenic profile of a contaminated crop is determined not only by the predominant pathogenic species but also by the lesser species in the Fusarium community.

\section{Fusarium Mycotoxins}

The most common Fusarium mycotoxin groups are trichothecenes, zearalenones and fumonisins (Figure 1); however, other mycotoxins (enniatins, moniliformin, beauvericin and fusaproliferin) can be identified in combination with the above-mentioned toxins [45].

A

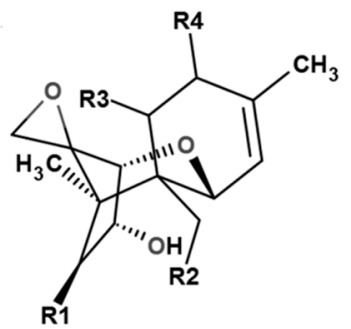

$\operatorname{DON}(\mathbf{R} 1=\mathrm{H} ; \mathbf{R} 2=\mathrm{OH} ; \mathbf{R} 3=\mathrm{OH} ; \mathbf{R} 4=\mathrm{O})$ $\mathrm{NIV}(\mathbf{R} \mathbf{1}=\mathrm{OH} ; \mathbf{R} 2=\mathrm{OH} ; \mathbf{R} 3=\mathrm{OH} ; \mathbf{R} 4=\mathrm{O})$ $\mathrm{T}-2 \quad(\mathbf{R} 1=\mathrm{OAc} ; \mathbf{R} 2=\mathrm{OAc} ; \mathbf{R} 3=\mathrm{H} ; \mathbf{R} 4=\mathrm{OIsoval})$ HT-2 (R1=OH; R2=OAc; R3=H; R4=OIsoval)<smiles>COC(C)CCCC(=O)CCC/C=C/c1cc(O)cc(O)c1C(=O)O</smiles>

\section{C}<smiles>[R2]C(CCCCC([R2])C[C@@H](C)C[C@H](OC(=O)C[C@H](CC(=O)O)C(=O)O)[C@@H](OC(=O)C[C@H](CC(=O)O)C(=O)O)[C@@H](C)CCCC)C[C@H](O)[C@@H](C)N</smiles>

$\mathrm{FB}_{1}(\mathbf{R} 1=\mathrm{OH} ; \mathbf{R} 2=\mathrm{OH})$ $\mathrm{FB}_{2}(\mathbf{R} 1=\mathrm{OH} ; \mathbf{R} 2=\mathrm{H})$

Figure 1. Chemical structure of the main Fusarium mycotoxins. (A) Trichothecenes; (B) Zearalenone; (C) Fumonisins; OAc = acetyl function; OIsoval = isovalerate function.

The recently published levels of mycotoxin contamination in main countries and selected regions of the world, according to the importance of the amount of cereals produced are presented, in Tables 1-4 below. Because no recent data were found on the overall mycotoxin contamination in different countries, what is shown here are the mycotoxin levels in different geographical areas, which, although not fully representative, can provide a comparison term between the measured contents and the stringent European normative. For this reason the tables show, where present, the percentage of samples that exceed European limits.

The distribution of mycotoxins in different regions is determined not only by the environmental conditions that affect Fusarium populations but also by endogenous and exogenous factors that can affect mycotoxin production. 
Table 1. Percentage and level of contamination in different countries and commodities relative to deoxynivalenol.

\begin{tabular}{|c|c|c|c|c|c|c|}
\hline Country & Cereal & Contamination Range (ppb) & Samples & Incidence $(\%)$ & Samples Over Limits & Ref. \\
\hline Argentina & Maize & n.d. -3600 & 3246 & 1.1 & $+($ n.a. $)$ & [46] \\
\hline Brazil & Wheat & $183-2150$ & 150 & 97 & $+(3.3 \%)$ & [47] \\
\hline Canada & Durum wheat & n.d. -4700 & 54 & 75 & $+($ n.a. $)$ & [48] \\
\hline \multirow{2}{*}{ China } & Maize & $3.3-834.4$ & 132 & 77 & - & [49] \\
\hline & Wheat & $2.4-1130$ & 672 & 91.5 & - & [50] \\
\hline \multirow{2}{*}{ Croatia } & Maize & $215-2942$ & 63 & 71 & $+(6 \%)$ & \multirow{2}{*}{ [51] } \\
\hline & Wheat & $115-278$ & 51 & 65 & - & \\
\hline \multirow{3}{*}{ Finland } & Barley & n.a. -1180 & 34 & 82.4 & - & \multirow{3}{*}{ [52] } \\
\hline & Oat & n.a. $-23,800$ & 31 & 100 & $+(32 \%)$ & \\
\hline & Wheat & n.a. -5510 & 30 & 96.7 & $+(23 \%)$ & \\
\hline \multirow{2}{*}{ Italy } & Durum wheat & n.d. $-14,452$ & 240 & 76.5 & $+($ n.a. $)$ & [53] \\
\hline & Maize & $3-428$ & 140 & 21.4 & - & [54] \\
\hline Morocco & Wheat & $121-1480$ & 80 & 5 & - & [55] \\
\hline Poland & Maize & n.d. -90 & 30 & 66.6 & - & [56] \\
\hline Sweden & Wheat & n.a. -6460 & 125 & 82 & $+(2.4 \%)$ & [57] \\
\hline Syria & Wheat & $9-550$ & 40 & 22.5 & - & [58] \\
\hline Tanzania & Maize & $68-2196$ & 60 & 63 & $+(5 \%)$ & [59] \\
\hline
\end{tabular}

Table 2. Percentage and level of contamination in different countries and commodities relative to T-2 and HT-2 toxins.

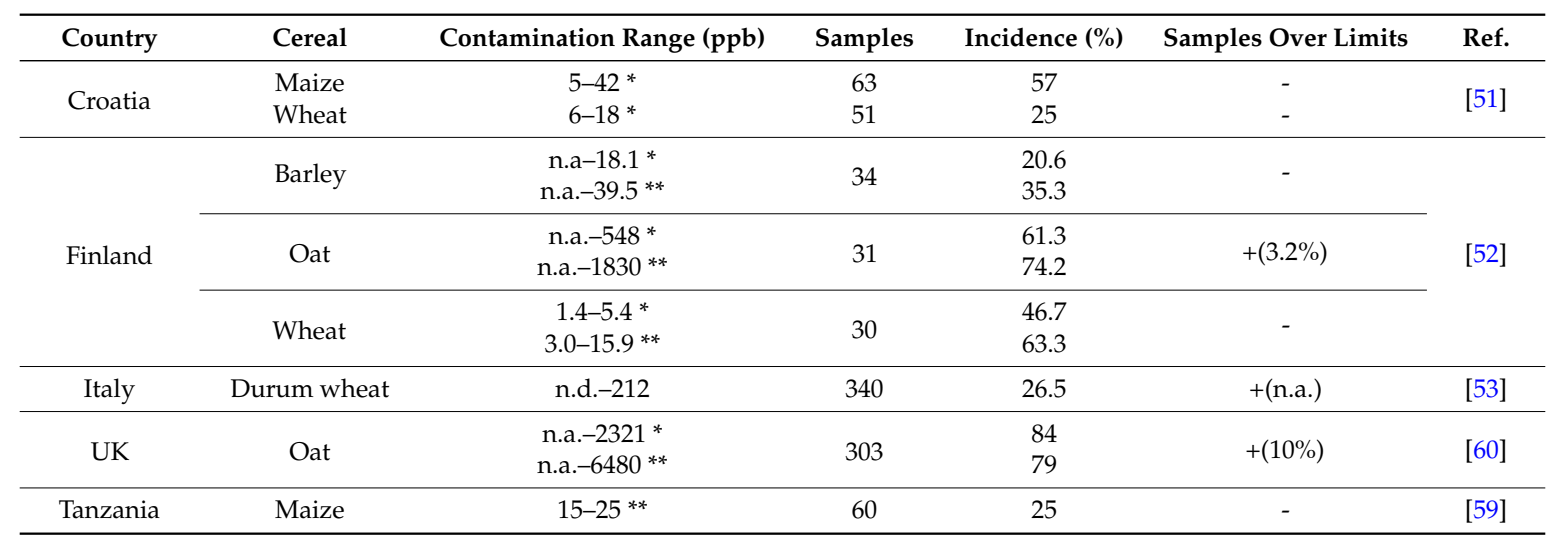

Limits are referred to European regulation, recommended limits are intended for sum of T-2 and HT-2 toxins; n.d.: not detected; n.a.: data not available; * amount of T-2; ** amount of HT-2.

Table 3. Percentage and level of contamination in different countries and commodities relative to zearalenone.

\begin{tabular}{|c|c|c|c|c|c|c|}
\hline Country & Cereal & Contamination Range (ppb) & Samples & Incidence $(\%)$ & Samples Over Limits & Ref. \\
\hline Argentina & Maize & n.d. $-10,000$ & 3246 & 2.7 & $+($ n.a. $)$ & [46] \\
\hline Brazil & Wheat & $20.4-233$ & 150 & 32 & $+(4 \%)$ & [47] \\
\hline \multirow[b]{2}{*}{ Croatia } & Maize & $10-611$ & 63 & 78 & $+(6 \%)$ & \multirow[b]{2}{*}{ [51] } \\
\hline & Wheat & $7-107$ & 51 & 69 & - & \\
\hline Egypt & Maize & $0.8-3.5$ & 50 & 70 & - & [62] \\
\hline \multirow{2}{*}{ Finland } & Oat & n.a. -675 & 31 & 41.9 & $+(3.2 \%)$ & \multirow[t]{2}{*}{ [52] } \\
\hline & Wheat & n.a. -234 & 30 & 46.7 & $+(3.3 \%)$ & \\
\hline Italy & Maize & n.d. -53 & 140 & 0.7 & - & [54] \\
\hline Poland & Maize & n.d. -59.9 & 30 & 43.3 & - & [56] \\
\hline Sweden & Wheat & n.d. -678 & 125 & 46 & $+($ n.a) & [57] \\
\hline
\end{tabular}

Limits are referred to European regulation; n.d.: not detected; n.a.: data not available. 
Table 4. Percentage and level of contamination in different countries and commodities relative to $B_{1}$ and $\mathrm{B}_{2}$ fumonisins.

\begin{tabular}{|c|c|c|c|c|c|c|}
\hline Country & Cereal & Contamination Range (ppb) & Samples & Incidence (\%) & Samples Over Limits & Ref. \\
\hline \multirow{3}{*}{ Argentina } & Durum wheat & $0.15-1304$ * & 40 & 77 & - & [64] \\
\hline & Maize & n.d. $-498,212$ & 3246 & 97.6 & $+($ n.a. $)$ & [46] \\
\hline & Wheat & $0.16-680 *$ & 135 & 97 & - & [64] \\
\hline \multirow[b]{2}{*}{ Brazil } & Cereal mix & n.d. -1876 * & 105 & 83.8 & $+(2 \%)$ & [65] \\
\hline & Maize & $66-7832 *$ & 232 & 46.6 & $+($ n.a. $)$ & [66] \\
\hline \multirow{2}{*}{ China } & Maize & n.d. $-22,362$ & 146 & 39.7 & $+(1.4 \%)$ & [67] \\
\hline & Wheat products & $0.3-34.6$ * & 362 & 6.4 & - & [68] \\
\hline \multirow{2}{*}{ Croatia } & Maize & n.d. -4438 & 63 & 90 & $+(1.6 \%)$ & \multirow{2}{*}{ [51] } \\
\hline & Wheat & n.d.- -203 & 51 & 39 & - & \\
\hline Egypt & Maize & $59-1915$ * & 20 & 100 & - & [62] \\
\hline Guatemala & Maize & $10-17100$ * & 640 & 98 & $+(20 \%)$ & [69] \\
\hline Italy & Maize & n.d.-21007 & 140 & 97.8 & $+(25.6 \%)$ & [22] \\
\hline Poland & Maize & $59-1190$ * & 30 & 100 & - & [56] \\
\hline Syria & Wheat & n.d. -6 * & 40 & 10 & - & [58] \\
\hline South Africa & Maize & $10-33,260$ & 288 & 30 & $+(16.6 \%)$ & [70] \\
\hline Tanzania & Maize & $16-18184$ * & 60 & 73 & $+(15 \%)$ & [59] \\
\hline
\end{tabular}

Limits are referred to European regulation, recommended limits are intended for sum of $B_{1}$ and $B_{2}$ fumonisin; n.d.: not detected; n.a.: data not available; * amount of $B_{1}$ fumonisin.

\subsection{Trichothecenes}

Trichothecenes (Figure 1A) comprise a vast group of metabolites containing an epoxide, which is responsible for their toxicological activity. Trichothecenes produced by Fusarium spp. are widespread in all cereal-growing areas of the world and they are divided into two groups: A and $\mathrm{B}$, mainly characterized by the presence of different functional groups in the C-8 position of the trichothecene backbone [71]. The A group mainly includes T-2 and HT-2 toxins, diacetoxy- and monoacetoxy-scirpenol (DAS and MAS) and neosolaniol (NEO). The B group mainly includes deoxynivalenol (DON), nivalenol (NIV), 3-AcetylDON, 15-AcetylDON and fusarenone $X[72,73]$. Fusarium langsethiae, F. equiseti, F. poae, and F. sporotrichoides produce type A trichothecenes while F. culmorum and F. graminearum typically produce type B trichothecenes. However, recently identified strains of $F$. graminearum are able to produce in wheat new trichothecenes (named NXs) with a structure similar to the type A [74]. Therefore, a strict separation among types of trichothecenes belonging to specific Fusarium species does not appear to be useful for systematic separation.

DON and NIV are the main type B trichothecenes found in Fusarium-infected kernels. A worldwide prevalence of DON-producers Fusarium graminearum complex species is known [75]; however, the occurrence of populations with high predominance of NIV-producers has been reported [76]. Deoxynivalenol (DON), also known as vomitoxin, is the most frequently occurring trichothecene in small cereals and maize used for food and feed production [77]. DON can also be present as mono-acetylated (3-AcDON, 15-AcDON) and di-acetylated (3,15-AcDON) derivatives [37]. DON has the potential to cause chronic effects such as reduced growth and anorexia, as well as acute intoxication leading to vomiting (emesis), immunotoxic effects and changes in brain neurochemicals [78]. In pigs, DON is also implicated in reproductive disorders with direct effects on ovarian function [79] and similar effect are presumed in cattle [80].

Nivalenol (NIV) is one of the well-known type B trichothecenes and usually occurs with other toxins among which DON, DAS and T2 [81,82]. With respect to the harmfulness of toxins, NIV is more toxic than DON towards animals [83] while DON is more toxic against plants [73]. NIV is a potent inhibitor of protein, RNA and DNA synthesis in mammalian cells and can cause necrosis of cells, especially in tissues that are rapidly growing and dividing as intestinal epithelial cells $[84,85]$. NIV can be present as di-acetylated derivatives, i.e., 4,15-AcNIV, produced by some strains of $F$. graminearum, F. cerealis, F. poae and F. culmorum [86]. Due to the ecology of the main producing species, NIV has 
usually been reported in cereal during years that are characterized by relatively drier and warmer growing seasons (with respect to DON) [87]. Generally, NIV contamination of cereals appears to be lower than DON $[57,88]$, the low exposures to nivalenol, based on the available occurrence data in food, led EFSA to consider nivalenol not a health concern [89].

T-2 and HT-2 toxins are type A trichothecenes produced by several Fusarium spp., mainly Fusarium langsethiae, F. sporotrichioides and F. poae in small grains and are most commonly present in oat. F. langsethiae and F. sporotrichioides are considered to be the main producers of T-2 and HT-2 toxins, especially in Northern Europe [90,91]. T-2 is rapidly metabolized in vivo to HT-2, which induces adverse effects similar to T-2, with non-remarkable differences in terms of strength [92]. Being a potent inducer of oxidative stress and an inhibitors of DNA, RNA, protein synthesis and mitochondrial function, T-2 and HT-2 toxins represent contaminants that are of considerable concern for human and animal health $[93,94]$. Furthermore, T-2 and HT-2 contamination can occur with diacetoxyscirpenol (DAS) [41,95], that is expectable because DAS is biosynthesized at a side branch of the T-2 toxin pathway [96].

\subsection{Zearalenone}

Zearalenone (ZEA, Figure 1B), a phenolic resorcylic acid lactone, is a mycotoxin that may occur in the form of four hydroxyl derivatives [3]. ZEA is of major interest because despite its low acute toxicity, it has proven to be hepatotoxic, immunotoxic, and carcinogenic to a number of mammalian species [97]. Moreover, ZEA and some of its metabolites have been shown to competitively bind to estrogen receptors in a number of different species and are responsible for hyper-estrogenism and infertility in livestock [98]. ZEA is mainly produced by F. graminearum, F. culmorum, F. cerealis, F. equiseti and F. semitectum [99] and the contamination often co-occurs with DON. It is a common Fusarium mycotoxins in the temperate regions of America [47], Europe [100] and Asia [101], but also present in Africa [63]. This toxin has a worldwide distribution with differences in the percentage and level of contamination, which are generally lower compared with the most representative trichothecenes (DON) [102].

\subsection{Fumonisins}

Fumonisins (Figure 1C) are a group of polyketide-derived mycotoxins that have a wide geographic distribution, and are consequently most commonly present on maize in many different regions [103]. Although up to 13 Fusarium species are able to produce fumonisins [104], F. verticillioides and F. proliferatum are the most important species associated with fumonisin contamination. Fumonisins can cause severe disorders in animals [105], apoptosis as consequences of membrane lipid peroxidation [106]. Consumption of fumonisin-contaminated maize has been associated with esophageal cancer and embryonal neural tube defects in humans [107]. Fumonisins can be separated into four main groups, identified as the fumonisin A, B, C, and P series [108]; the B group includes the most active fumonisins $\mathrm{FB}_{1}$ and its isomers $\mathrm{FB}_{2}, \mathrm{FB}_{3}$ and $\mathrm{FB}_{4}$ [109]. In particular, $\mathrm{FB}_{1}$, which causes considerable toxicological concern, is the most abundant fumonisin produced in maize. $\mathrm{FB}_{1}$ accounts for $70 \%-80 \%$ of total fumonisins compared with $15 \%-25 \%\left(\mathrm{FB}_{2}\right), 3 \%-8 \%\left(\mathrm{FB}_{3}\right)$ and $1 \%-2 \%\left(\mathrm{FB}_{4}\right)$ [110]. Fumonisin contamination of cereals is a worldwide concern, and F. verticillioides is the main fumonisin producer. In regions characterized by temperate-warm conditions, a high incidence of fumonisin contamination is usually present [111].

On the base of differences in the levels of mycotoxin contamination that can be observed worldwide, it appears evident that in different environments and in particular when the weather conditions are unfavorable or in absence of appropriate management the levels of contamination can exceed the maximum and tolerable limits. So, the adoption of forecast models and appropriate management strategies at the production stages to contain mycotoxin occurrence appears encouraged. The different regulations on mycotoxin levels must be considered in view of a global market and since European regulations appear stringent, a common strategy looks like the best way for food safety. 


\subsection{Emerging Fusarium Toxins}

Beyond to the most common Fusarium toxins, others considered emerging have been reported in huge quantities and the contamination seems to be related to climate condition and cereal type. Among the emerging mycotoxins, enniatins, beauvericin, fusaproliferin and moniliformin represent a potential health treat to investigate.

Enniatins (ENs) and beauvericin (BEA) are mycotoxins produced by several Fusarium species that are known to contaminate cereals and by-products $[112,113]$. These toxins show similar chemical structures and present the same toxic dynamic actions, exhibiting antibiotic, antimicrobial, insecticidal and cytotoxic effects. Further, they are easily incorporated into cellular membranes, disturbing the physiological ionic balance, which affects cell homeostasis [114]. For several cell lines, cytotoxicity of these mycotoxins has been demonstrated to inhibits cell proliferation modifying cell cycle phases and increasing apoptosis induce apoptosis and mitochondrial damage [115].

ENs are six-membered cyclic depsipeptides, consisting of at least 23 different compounds that have been described as naturally occurring enniatin analogues [116,117]. However, the more common analogues are the enniatins $B_{1}$ and $A_{1}$. Enniatin occurrence is typically high in Northern and Eastern Europe barley and wheat $[57,118]$ with incidence up to $100 \%$, but also Mediterranean climate can favors the growth of toxigenic molds that produce ENs. An analysis conducted on cereals from Spain indicated that frequencies of EN contamination were $89 \%, 62 \%$ and $50 \%$ for maize, wheat and barley, respectively [119]. Similar high incidences were found in Morocco [120] and Tunisia [121], although at low levels.

BEA is a mycotoxin of the cyclohexadepsipeptide family. It has been found as a natural contaminant of cereal in Europe [122], Africa [123], America [48] and Asia [124]. Fusarium poae, mainly, but also F. avenaceum, F. temperatum and many others have been described as producers of BEA $[125,126]$. BEA was found to be present in $26.5 \%$ of Moroccan cereals samples with a maximum contamination in maize [120], while low contamination was found in cereals from Portugal [127] and Mexico [128]. In Argentina, potentially contaminated maize samples were observed [126] while no contamination was reported for wheat [129].

Fusaproliferin (FUS) is a bicyclic sesterterpene produced by Fusarium proliferatum, F. subglutinans, F. antophilum, F. begoniae, F. bulbicola, F. circinatum, F. pseudocircinatum, F. guttiforme, F. concentricum, F. succisae, F. udum [130] and F. temperatum [126]. FUS can usually be found in a deacetylated form in a 3:1 ratio [131]; however, the deacetylated form shows a limited toxicological activity compared with FUS [132]. This compound is toxic to brine shrimp (Artemia salina L.), insect cells and mammalian cells, and causes teratogenic effects in chicken embryos $[130,132,133]$. The production of FUS by F. proliferatum strains and the natural co-occurrence of these mycotoxins in maize samples contaminated by Fusarium species have been reported in Italy, South Africa and USA [132,134,135]. Data indicated weak FUS contamination levels in cereals from Morocco [120], but no contamination was observed for samples from Tunisia [121]. FUS was very common in maize in Mexico [128], but at very low levels, while it was not detected in wheat in Argentina [129].

Moniliformin (MON) is a small and highly polar molecule present in nature as a water-soluble sodium or potassium salt [136]. Fusarium species most frequently associated with MON production throughout the world are F. proliferatum, F. verticillioides, F. subglutinans, F. avenaceum, F. chlamydosporum, F. oxysporum and F. tricinctum [1,137]. Fusarium avenaceum appears to be the most important producer of moniliformin (MON) and ENs, at least in the Nordic countries [45].

The molecular mechanism of MON action is unknown; however, because of its structural similarity to pyruvate, MON probably affects metabolic pathways involving pyruvate and the inhibition of the oxidation of tricarboxylic acid (TCA) cycle intermediates, resulting in respiratory stress [138]. The occurrence of moniliformin in cereals and cereal products has been reported for different regions worldwide [139], and variable levels have been recorded. Recently, levels up to $2500 \mu \mathrm{g} / \mathrm{kg}$ were reported in maize samples from northern Italian fields [140], with an overall incidence of $93 \%$ positive samples. High MON levels were also find in Nordic wheat and maize, with lower levels in barley and 
oats $[141,142]$. MON contamination of Canadian durum wheat, soft wheat, rye and oat samples was $75 \%, 56 \%, 33 \%$ and $16 \%$, respectively [48].

\section{Legislation on Fusarium Toxins in Cereal}

Mycotoxins are one of the most important risks associated to cereals consumption [143] and in some cases they may also have a negative impact on the quality of the food and feed. To preserve the public health and livestock production by mycotoxin occurrence the countries developed measures as the introduction of maximum or recommended levels for food and feedingstuff.

Internationally, Codex Aliment Arius Commission (CAC) issues legislation on food and feedstuff. The CAC, established by World Health Organization (WHO) and Food and Agriculture Organization (FAO), has issued international standards, guidelines and codes of practice for the prevention and reduction of mycotoxin contamination in several foods and feeds; in CAC/RCP 51-2003 document are included Fusarium toxins in cereals [144].

Among factors that play a major role on defining limits and regulations for mycotoxins are included the availability of toxicological and exposure data, the knowledge of the distribution of mycotoxin concentrations in commodity and these limits are provided for mycotoxin/matrix combination [145]. The CAC has recently proposed a draft of the maximum limits for human consumption of DON in raw wheat, maize, barley grains and their derivatives at 2000 and $1000 \mathrm{ppb}$, respectively; fumonisins in unprocessed maize grain and derivatives at 4000 and $2000 \mathrm{ppb}$, respectively [146].

Specific regulations at country level are proclaimed by authoritative bodies, for example, European Commission, Food and Drug Administration of United States (U.S. FDA), Public Health Agency of Canada (PHAC), Health Surveillance Agency for Brazil (ANVISA), Food and Drug Administration of China (CFDA) and the Russian Federal Service for Surveillance on Consumer Rights Protection and Human Wellbeing (Rospotrebnadzor).

Due to the heterogeneity of commodities produced and consumed, the European regulation on mycotoxins is probably the most complete, comprising the majority of contaminant toxins; therefore the comparison of limits of Fusarium toxin was performed on the base of European levels. In Table 5 are listed the limits established by authoritative bodies for mycotoxin contamination in Europe. Despite the great worldwide production of rice, this cereal will not discussed in this review given the low contamination levels of Fusarium toxins in polished products for human consumption compared to the other small cereals $[147,148]$. Over the years, the number of countries with known specific mycotoxin legislation has increased with particular emphasis to the main food and feed cereal commodities produced or traded by a specific country. Outside Europe, in the main cereal producing countries, e.g., in Brazil, Fusarium mycotoxin regulation, in effect since 2016, indicates the maximum tolerable limits for deoxynivalenol in whole wheat and wheat derivatives at 1000 and 750 ppb, respectively. About zearalenone the maximum tolerable limits in whole wheat, wheat flour and derivatives, maize and derivatives are 200, 100 and 150 ppb, respectively. About fumonisins the maximum tolerable limits in maize meal and other maize-based products are 1500 and 1000 ppb, respectively [149].

In Canada, Fusarium mycotoxin regulation in food establishes tolerable level of deoxynivalenol in uncleaned soft wheat at $2000 \mathrm{ppb}$ (under review) [150]. In China, Fusarium mycotoxin regulation in food establishes the maximum level for deoxynivalenol in wheat, barley, maize and derivatives at 1000 ppb; about zearalenone the maximum levels in wheat and maize are 60 ppb [151]. In Russia, Fusarium mycotoxin regulation in food establishes the maximum level for deoxynivalenol in wheat, barley and their derivatives at 700 and 1000 ppb, respectively. About T2 in food grain and their derivatives limit is $100 \mathrm{ppb}$; about zearalenone in wheat, barley and maize maximum levels is $1000 \mathrm{ppb}$. About fumonisin in maize flour permissible levels are not more than $200 \mathrm{ppb}$ [152]. Finally, the U.S. Food and Drug Administration (FDA) recommends that DON levels in human foods should not exceed $1000 \mathrm{ppb}$. About fumonisins in degermed dry milled corn products and cleaned maize used for popcorn limit levels are 2000 and 3000 ppb, respectively [153,154]. 
Table 5. Limits relate to human consumption according to European Commission.

\begin{tabular}{|c|c|}
\hline \multicolumn{2}{|l|}{ Deoxynivalenol in Food [89] } \\
\hline Commodity & Maximum Level (ppb) \\
\hline Unprocessed cereals (excluding durum wheat, oats and maize) & 1250 \\
\hline Unprocessed durum wheat and oats & 1750 \\
\hline Unprocessed maize & 1750 \\
\hline $\begin{array}{l}\text { Cereals intended for direct human consumption, cereal flour, bran and germ as } \\
\text { end product marketed for direct human consumption }\end{array}$ & 750 \\
\hline \multicolumn{2}{|l|}{ T-2 and HT-2 in Food [93] } \\
\hline Commodity & $\begin{array}{l}\text { Maximum Level Sum of } \\
\text { T-2 and HT-2 (ppb) }\end{array}$ \\
\hline Barley (including malting barley) and maize & 200 \\
\hline Oats (with husk) & 1000 \\
\hline Wheat, rye and other cereals & 100 \\
\hline Oats for direct human consumption & 200 \\
\hline Maize for direct human consumption & 100 \\
\hline Other cereals for direct human consumption & 50 \\
\hline \multicolumn{2}{|l|}{ Zearalenone in Food [89] } \\
\hline Commodity & Maximum Level (ppb) \\
\hline Unprocessed cereals other than maize & 100 \\
\hline Unprocessed maize & 350 \\
\hline $\begin{array}{l}\text { Cereals intended for direct human consumption, cereal flour, bran and germ as } \\
\text { end product for direct human consumption }\end{array}$ & 75 \\
\hline $\begin{array}{l}\text { Maize intended for direct human consumption, maize based snacks and maize } \\
\text { based breakfast cereals }\end{array}$ & 100 \\
\hline \multicolumn{2}{|l|}{ Fumonisin in Food [89] } \\
\hline Commodity & $\begin{array}{l}\text { Maximum Level Sum of } \\
B_{1} \text { and } B_{2}(p p b)\end{array}$ \\
\hline Unprocessed maize & 4000 \\
\hline Maize intended for direct human consumption & 1000 \\
\hline Maize based breakfast cereals and maize based snacks (a) & 800 \\
\hline
\end{tabular}

As previously reported, toxicosis in animal fed with feedstuff contaminated by Fusarium toxins led to a worsening in animal productivity and general healthiness, resulting in increased susceptibility to parasites and diseases. To reduce issues related to mycotoxin occurrence in feedstuff, legislation ruled the presence of these compounds in products intended for animal feeding. For an illustrative purpose, in Table 6 are listed the European recommended guidance values relative to feedstuffs.

Table 6. Limits relate to cereals intended for animal feed according to European Commission.

\begin{tabular}{lc}
\hline Deoxynivalenol in Feedstuff [155] & \\
\hline Commodity Intended for Animal Feed & Guidance Value (ppm) \\
\hline Cereals and cereal products with the exception of maize by-products & 8 \\
Maize by-products & 12 \\
Complementary and complete feedingstuff & 5 \\
$\quad$-exception for pigs & 0.9 \\
-exception for calves (<4 months), lambs and kids & 2 \\
\hline
\end{tabular}


Table 6. Cont.

\begin{tabular}{lc}
\hline T-2 and HT-2 in Feedstuff [156] & Indicative Levels Sum \\
Cof T-2 and HT-2 (ppm)
\end{tabular}

\section{Factors affecting Fusarium Toxins Production}

\subsection{Effect of Climate Events on FHB, Maize ear Rots and Mycotoxin}

Climate is among the most important factors influencing the occurrence and distribution of Fusarium. Different climatic conditions (e.g., temperature and rainfall) in different geographical locations affect the incidence of pathogens responsible for FHB of small grain cereals and ear rots of maize. The relationships between climatic factors and FHB development have been thoroughly investigated [14,157]. Well define ranges of temperature and water availability are determining factors for the growth of Fusarium and mycotoxin production [42]. Warm and moist conditions, especially during the period of anthesis, are considered critical factors for FHB development. Among the FHB causal agents, the fungal species vary on a regional and continental scale and during any given season $[158,159]$. It is conceivable to suggest that under the influence of climatic changes, modifications in the total and relative abundance of fungal species of the FHB complex may occur. Changes in climatic extremes would have direct impacts on Fusarium ear disease and mycotoxin production because weather factors can strongly affect epidemics and the proportions of the species responsible for FHB and ear rots [160]. These changes could also influence the production of DON by the two main DON-producing fungal species, F. graminearum and F. culmorum, as well as the production of fumonisins by the main producer, i.e., F. verticillioides. In fact, temperature that may be optimal for growth, are different from those optimal for mycotoxin synthesis by F. graminearum, F. culmorum and F. verticillioides [161,162].

In maize, climatic factors determine the balances that occur within Fusarium populations. Maize ear rots are caused by a mixture of pathogens that compete among themselves. It is generally recognized that negative interactions in competition between Fusarium spp. are prevalent. GER and FER are favoured by distinct climatic conditions: GER is favoured by high levels of moisture at silking, followed by moderate temperatures and high rainfall during the maturation period [163] while FER is more common in warmer and drier areas [37]. In fact, F. verticillioides prefers a higher 
temperature of $30^{\circ} \mathrm{C}$ and tolerates water stress better than F. graminearum. Fumonisin contamination is highly dependent on the composition of the Fusarium community as well as environmental conditions, and fumonisin incidence can be high or low in relation to the growing areas. Several evidence indicates that water stress during drought events is strongly associated with high levels of F. verticillioides infection and fumonisin accumulation in kernels [27]. In particular, the factors that affect fumonisin development include environmental factors (temperature, humidity), insect damage and pre-/post-harvest management.

More, F. verticillioides isolates were found to exhibit better performance at higher temperatures and under water stress conditions in comparison to F. proliferatum, another fumonisin producing species [164]. The levels of $\mathrm{FB}_{1}$, the most abundant and toxicologically active fumonisin, were found to be absent or significantly low in areas generally characterized by cold and wet seasons [165]; however, under favourable conditions in these areas, fumonisins reached significant levels [166].

\subsection{Fungal Interactions in Cereals: Consequences for Fusarium Development and Mycotoxin}

Interactions among fungal species depend on biotic and abiotic factors and can play an important role in the structural organization of fungal communities. These interactions range from antagonistic to mutualistic and can be positive, negative or neutral [167]. Through different mechanisms (competition for space and feed resources), some pathogenic species may have an advantage over other fungal species that occupy the same niche, hindering the development of less competitive fungi [168]; on the contrary, one fungal species can improve the adaptability of other species [169]. Therefore, the role of ecological interactions is of particular importance because these interactions can significantly affect fungal development and secondary metabolism. It is critical to take this into account to accurately assess the risk of mycotoxin contamination. Moreover, host-specific influences on intraspecific competition may dictate fungal compositions and probably mycotoxin occurrence as observed in A. flavus populations [170]. Several studies on interspecific interactions between only Fusarium spp. or between Fusarium spp. and other genera have been carried out under in vitro conditions [171,172], whereas only a few have been conducted under natural conditions [173] Negative interactions in fungal communities that occupy the same ecological niche are predominant and are based principally on competition [174,175].

In small grain cereals, FHB is generally associated with various fungal species, including both toxigenic (several species of Fusarium) and non-toxigenic fungi (Microdochium spp.), and their prevalence and abundance in the same field [176,177] are strongly dependent on environmental variables. Due to environmental variables under field conditions, FHB development and mycotoxin production are predicted to be more complex when more than one toxigenic species is present. Also the role of conidia has been evaluated and studies on interactions between several FHB species have shown that among Fusaria the species producing macroconidia are the most competitive during germination [178]. Experimental evidence supports any synergetic interactions between single isolates of F. graminearum, F. poae, F. culmorum and F. avenaceum after inoculation on wheat spikes, while in most cases, the presence of competitive interactions is more evident. In the presence of a mixed FHB infection, a large reduction in fungal biomass has been observed in comparison to single inoculations. On the contrary, mycotoxin productivity per unit of fungal biomass was found to increase dramatically in the co-inoculations, indicating that the production of trichothecene mycotoxins can be affected by competition [173]. Some experimental studies performed in wheat do not confirm these results where intraspecies interaction appears to reduce trichothecene yield [179]. Recent findings suggest that the behaviour of different isolates in presence of a competitor is variable mostly depending by Fusarium strain rather than species, with a predominance of aggressive isolates [180]. However, this study also demonstrates a lack of correlation between co-occurrence of several FHB species and an increase of Fusarium toxins risk in wheat production.

In maize, in competition with other genera that commonly co-occur on kernels, F. verticillioides has been found to take advantage of Aspergillus flavus and Penicillium spp. in mixed infections [181,182]. 
Towards other Fusarium species, inoculation of maize with isolates of F. verticillioides, F. proliferatum (fumonisin producers) and F. graminearum (DON and zearalenone producer), performed under different water and temperature conditions, showed that Fusarium populations generally decreased in presence of competitors in dependence of environmental variables. In addition, fumonisin production was generally reduced in competing interactions, whereas zearalenone was not affected and DON was increased [183]. These in vitro experiments indicated opposite results compared with those obtained from trials under natural conditions where $F$. verticillioides has been observed to inhibit the growth of F. graminearum [167]. It is known that $F$. verticillioides has a competitive advantage over $F$. graminearum when simultaneously inoculated due to better growth and a higher spore germination rate over a wider range of temperatures and water activities [167]. However, the impact of these interactions on mycotoxin contamination requires further investigation with respect to environmental and stress conditions. Indeed, it was demonstrated that high levels of $F$. verticillioides do not necessarily result in high levels of fumonisin contamination [184]. Insensitivity of ZEA and DON producers to competition also occurred when F. graminearum was cultivated with Aspergillus parasiticus, and the toxin levels were not modified [185].

\subsection{Stress Factors}

Depending on their environmental growth conditions, fungi sense a variety of external signals and respond by regulating secondary metabolism [186]. Field crops are continuously challenged by several environmental stresses that occur naturally in a certain area. Cereal growth, productivity and resistance to pathogens are closely related to environmental and agronomical input, which are both related to the response of crop plants to stress. Stress conditions imposed on developing crops, especially during the reproductive stage, can facilitate fungal infection, mycotoxin production and grain contamination [187].

Biotic factors such as insects, pathogens and weeds [188-190] and abiotic factors such as hot temperatures, drought and hailstorms [191] can affect crop physiology and productivity [192] and may result in conditions that are favourable for mycotoxin accumulation. There is evidence that the abiotic and biotic factors that predispose plants to diseases can activate several plant responses to stress, which can indirectly influence mycotoxin production [193]. In response to biotic and abiotic stress, plants react with a rapid and transient release of reactive oxygen species (ROS), activating a broad range of strategies to protect themselves [194-196]. Because oxidative stress in fungi was demonstrated to modulate in vitro the biosynthetic pathways of Fusarium mycotoxins such as trichothecenes and fumonisins [197,198], it is conceivable to suggest that an alteration of the cellular redox state in planta can affect mycotoxin accumulation.

One of the primary biotic stress factors that influence fungal colonization and mycotoxin contamination are the insects. As a consequence of phytophagous insect attack, the harmful action of insects occurs in two ways: by producing wounds that are favourable entry sites for conidia already present on the ear tissues and by causing stress conditions in plant tissues [199] through the generation of ROS [200]. ROS generation in plant was suggested to be a common response that persists on as long as the insect attack carries on. Although the effect of insect activity on small cereal is low, insects can still be considered a potential risk for the occurrence of FHB. In fact, pre-exposal of wheat ears to aphids as Rhopalosiphum padi and Sitobion avenae, can co-occur with FHB appearance and lead to a significant increase in F. graminearum colonization and DON accumulation [201,202]. These results are probably related to the elicitation of defense signalling pathways through accumulation of $\mathrm{H}_{2} \mathrm{O}_{2}$ and ROS [203] as well as enhancement of plant defence [202]. As regards to the redox potential, this can act as a modulator of DON biosynthesis [204] that, in turn, lead to a further accumulation of $\mathrm{H}_{2} \mathrm{O}_{2}$ in wheat tissues [205]. Recently, in F. graminearum the gene FGK3, recognized as an important virulence factor essential for pathogenicity and DON production, was demonstrated to be up-regulated in response to $\mathrm{H}_{2} \mathrm{O}_{2}$, cold and SDS stresses [206]. Concerning plant defence, the pathogen can produce 
more DON in an attempt to circumvent the enhanced defences, with the consequent acceleration of disease progression and mycotoxin accumulation [207].

In maize, F. verticillioides infection is facilitated by insect damage while $F$. graminearum mainly infect ear through the silks, therefore, the effect of insect stress is higher for FER pathogens respect to GER ones [5]. Recent evidence has also shown a correlation between ear-feeding insects and mycotoxin contamination in maize $[193,208,209]$, and other findings suggest that kernel-feeding insects are more important than silk- or cob-feeding insects [210]. Insects affecting maize such as Ostrinia nubilalis (European corn borer; ECB), Sesamia nonagrioides (Mediterranean corn borer), Helicoverpa zea (Corn earworm), and Sitotroga cerealella (Angoumois grain moth) can produce tunnels into stalks and ears and can carry F. verticillioides conidia and therefore transmit infection. Beyond to corn borers, also populations of ear-feeding insects as Frankliniella occidentalis (Western flower thrips) provide inoculum sites for Fusarium spp. and their presence are strongly correlated with disease severity and fumonisin contamination [24].

While it is difficult to distinguish the role of these actions in the fungal infection process and mycotoxin induction, at least for aflatoxin accumulation, it was reported that Aspergillus flavus infection mediated by a vector was more conducive than that mechanically mediated, demonstrating the importance of insects in mycotoxin occurrence [211]. Because of the increased level of ROS reported after insect attack on Lima bean and potato [212,213] also the interaction between maize and ECB should represent a stress condition; however, how this stress relates to mycotoxin induction requires further investigation.

The results from several studies suggest a role of ROS such as $\mathrm{H}_{2} \mathrm{O}_{2}$ in mycotoxin production by toxigenic Fusarium, as well as antioxidant compounds have been demonstrated to inhibit toxinogenesis $[198,214]$. The concomitance of multiple pathogens can positively influence Fusarium disease in cereals. In maize, the infection by ear-damaging pathogens as $F$. graminearum and F. subglutinans facilitates the subsequent $F$. verticillioides infection and fumonisin accumulation [215]. Further evidences are provided by infection of maize with Ustilago maydis where fumonisin levels resulted increased in the kernels harvested from smutted ears compared with the kernels from smut-free control ears [189]. Together, these data show that an initial infection can breach the host defense and weaken plants, allowing access to other pathogens, including toxigenic fungi, and promoting their performance.

Weeds represent a threat to the crop and also an indirect stress affecting the crop performance. As reported in maize, light competition with the perennial ryegrass Lolium perenne unfavourably modifies the pattern of plant growth and development. This interaction also highlighted as a first stress due to shade avoidance may affect sensitivity toward a subsequent abiotic stress [216]. Moreover, the light reflected from the tissues of the above-ground neighbouring weeds was found to reduce total root biomass [190], furtherly influencing ability of plant to adsorb water and nutrients. Finally, competition between crop plants and weeds for water, nutrients and sunlight involves the ability of a plant to respond to diseases and parasites and crop competition with weeds is presumed to increase sensitivity to soil-borne mutualists and pathogens [217].

Abiotic stress, such as hot temperatures and drought conditions, strongly alters the efficiency of photosystems and the stability of membranes, and is associated with oxidative stress in plants [196]. In fact, crop resistance to stress conditions can be related to high efficiency ROS-scavenging systems, as has been reported in wheat [218]. Because dry conditions typically accompany excessive heat, it is difficult to determine the influence of single factors. During kernel filling, drought and high temperature are considered as the environmental conditions that are most conducive to mycotoxin contamination in maize [219]. In Poland, it was reported that particularly high concentrations of fumonisins were associated with the hottest and driest summers [220]; however, other studies reported a low [24] or no influence of drought stress [221]. Moreover, during field trials conducted in Italy under climatic conditions that were considered unfavourable for Fusarium infections, a decrease in F. verticillioides colonization in maize was not related to an equal reduction in fumonisin accumulation. 
This result further suggests that hot conditions and drought stress play an important role in modulation of fumonisin production [184]. Environmentally damaging conditions such as hailstorms have also been reported to decrease quality [222] and increase mycotoxin contamination [191], favouring the entry of a fungal pathogen and causing plant stress. These authors reported that fumonisins were more frequently detected in grain from hail-damaged fields compared with undamaged fields. While an increase in the level of stress signalling following mechanical damage of leaf tissues has been well documented [223], the possibility that this type of meteorological event can stimulate mycotoxin biosynthesis through wound signals should be considered.

\section{Fusarium Disease and Toxins Management}

Good Agricultural Practices (GAPs) in cereals provides the adoption of measures in all phases of crop production able to interfere with the Fusarium spp. infection and toxins accumulation in grain. The agriculture practices, below described, can differently affect the levels of contamination of the different kind of toxins in maize and wheat. GAPs guidelines have been proposed to the Italian Ministry of Agricultural, Food and Forestry Policies [224], their importance and impact on the main mycotoxins is summarized in Table 7.

Table 7. Importance of GAPs for mycotoxins control.

\begin{tabular}{cccc}
\hline Practice & Small Cereal & \multicolumn{2}{c}{ Maize } \\
\hline & DON, T-2 and HT-2 & Fumonisin & DON and ZEA \\
\hline Soil tillage & $\mathrm{VH}$ & $\mathrm{L}$ & $\mathrm{S}$ \\
Crop rotation & $\mathrm{VH}$ & $\mathrm{L}$ & $\mathrm{S}$ \\
Hybrid selection & $\mathrm{H}$ & $\mathrm{H}$ & $\mathrm{VH}$ \\
Planting date & $\mathrm{L}$ & $\mathrm{S}$ & $\mathrm{VH}$ \\
Seed density & $\mathrm{L}$ & $\mathrm{L}$ & $\mathrm{S}$ \\
Weeding & $\mathrm{S}$ & $\mathrm{S}$ & $\mathrm{L}$ \\
Irrigation & $\mathrm{L}$ & $\mathrm{S}$ & $\mathrm{L}$ \\
Balanced fertilization & $\mathrm{S}$ & $\mathrm{VH}$ & $\mathrm{S}$ \\
Insecticide treatment & $\mathrm{L}$ & $\mathrm{L}$ & $\mathrm{L}$ \\
Fungicide treatment & $\mathrm{H}$ & $\mathrm{H}$ & $\mathrm{H}$ \\
Harvest time & $\mathrm{S}$ & $\mathrm{T}$ & \\
\hline
\end{tabular}

$\mathrm{VH}$ (Very High): Extremely important measure for the systemic nature and the remarkable effectiveness in reducing contamination; $\mathrm{H}$ (High): Frequently effective measure able to significantly reduce contamination; $\mathrm{S}$ (Significant): Often effective measure when it is accompanied by other very effective practices; L (Low): Sometimes effective measure or with reduced effect on contamination.

\subsection{Tillage and Crop Rotation}

Infected cereal debris, which are major sources of inoculum for Fusarium infection [225,226], decompose slowly [227] and can therefore be present in subsequent crops for at least two years [228,229]. With respect to tillage, conventional practices include to plough the soil and bury the remains of previous crops and weeds whereas in minimum or no tillage practices, seeds are directly drilled into the previous crop stubbles.

It is clear that conventional tillage systems alter, with different degrees for a limited time, the physical and chemical property of soil influencing the nutrient distribution and the organism microenvironment, altering microbial population, complexity and layer distribution [230] and these changes are likely influenced by soil structure and environment [231]. No-till management that avoid soil disturbance and increase organic matter modify the microbiota components favouring fungi as primary decomposers with respect to the bacteria [230]. Since complex indigenous fungal communities in arable soil, due to improvement in competition and antagonism, were linked to a role in suppression of soilborne pathogenic fungi as Fusarium spp. [232], no-till practices should represent the strategy to counteract Fusarium soilborne inoculum. 
Some studies, instead, evidenced any effect due to tillage systems for DON level in wheat [233], and also a lack of effects with respect to fumonisin in maize [234]. Furthermore, other authors reported that minimally prepared soil after a Fusarium-host crop was conducive to a high incidence of Fusarium disease and mycotoxin contamination of wheat and maize $[235,236]$, while any effect was detected when the previous crop was not a Fusarium-host plant [237]. These contrasting results suggest the crucial importance of agronomic and environmental factors that can vary in the years and areas in which each trial was carried out.

Although some authors consider adjacent crops as the main source of inoculum [238], others state that due to long-distance transport of viable spores of Gibberella zeae, the management of inoculum in individual fields has little or no impact on the regional epidemics of FHB [226,239]. However, among the practices affecting the occurrence of Fusarium disease, crop rotation is critical. It is commonly accepted that in cereals grown in monoculture or followed by alternative crops, the potential hosts of Fusarium pathogens are at a greater risk of fusariosis and also grain contamination can be related to different amounts of crop debris left on the soil [240]. Fusarium spp. population, involved in FHB, is characterized by a large variability and complexity according to location and type of substrate (weeds, crop residues, soil and residual ears) [241]. Evidence that debris of previous crops plays an important role in Fusarium infection is suggested by the observation that FHB spreads at the highest values when maize and wheat are adjacent or previous crop compared to a non-host such as soybean, [242].

\subsection{Cultivar Selection}

The use of cereal cultivars resistant to Fusarium disease can represent a valid tool to reduce mycotoxin occurrence and the right choice of cultivar is of primary importance, in particular for small cereals. Selection of cultivars in small cereals should take into account the constitutive resistance to FHB that can include: plant height [243], flowering type [244] and time [245], resistance to lodging [246] and trait loci for resistance to Fusarium disease. Recently, proteomic and transcriptomic analysis in wheat revealed that in FHB susceptible genotypes, F. graminearum infection is related to the delay of defense mechanism activation and that the pathogen take advantage of susceptibility factors to create an appropriate environment for its development $[247,248]$. FHB resistance is a quantitative trait controlled by multiple genes characterized by considerable variation [249]. Different resistance traits to FHB can be distinguished: the first related to prevent the initial infection (type I) [250], the second operating against fungal spread (type II) [251], a third related to the ability to resist kernel infection (type III) [252], and other two types including tolerance to infection (type IV) [253] or resistance to DON accumulation (type V) [254]. About type $\mathrm{V}$ toxin resistance two mechanisms have been proposed: $\mathrm{V}-1$, metabolic transformation of DON to less toxic glucosylated-compounds and V-2, inhibition of trichothecene biosynthesis. [255] Recently, a study on wheat cultivars with different degrees of FHB resistance reported that DON contamination levels did not increased consistently with the concomitant increase of disease incidence; moreover, DON levels in the most FHB sensitive varieties were not necessarily high [256].

In maize, the control strategy for ear rot can be implemented with the use of genetically resistant hybrids with traits unfavourable for fungal colonization and mycotoxin biosynthesis, but at our knowledge few Fusarium resistant hybrids has been recently commercialized. The genetic resistance to GER and FER, appear complex with many clustered quantitative trait loci (QTLs) that shown a possible pleiotropic effects on both disease resistance traits and mycotoxin accumulation [257-259]. These traits can involve grain hardness [260], the season length of hybrids [261], the physicochemical parameters $\left(\mathrm{pH}, \mathrm{a}_{\mathrm{w}}\right)$ of grains [262] the nutritional content of kernels [263] or accumulation of antiphenolic compounds [264]. Ear rot in maize can also be decreased by using Bt-maize, which limits corn-borer insect activity, disease occurrence and fumonisin contamination [265]. 


\subsection{Planting and Weed Management}

Management of planting date, with emphasis on early planting, was demonstrated to be important for Fusarium disease control in both wheat and maize cultivars $[30,266]$. The sowing date and the accurate choice of cereal varieties and maize hybrid, referred to the length of cultural cycle, determine the environmental conditions to which the crop is exposed during silking and grain filling to Fusarium inoculum and infection. Therefore, the right agronomic choices could be advantageous with respect to reducing fungal development and toxinogenesis [267]. Field experiments carried out to compare hybrids with different maturity revealed that the cultivation of the early maturing hybrids resulted in a reduced zearalenone contamination related to the conditions in which ripening occurs [260]. In planting management, optimal seed density varies among hybrids, and it is important to avoid the plant-to-plant competition for light, nutrients and water. This phenomenon was extensively investigated in maize and high density was demonstrated to cause a clear yield reduction in drought conditions [268] and a significant increase in fumonisin contamination. Moreover, an increment in plant density of $26 \%$ (from 65,000 to 82,000 plants. ha ${ }^{-1}$ ) was observed to determine higher values of ear rot severity $(+43 \%)$ and fumonisin content $(+153 \%)$ [269]. However, other studies reported any change in mycotoxin reduction lowering seeding density (from 98,800 to 49,400 plants. ha ${ }^{-1}$ ) [221].

Competition and interference between crop and weeds for water, nutrients and sunlight may predispose plant to be more susceptible to the effect of other stressors (shade avoidance ), therefore weed management is necessary to alleviate plant stress and improve crop production [187]. The impact of weeds on the development of Fusarium epidemics has also been correlated with their role as a source of inoculum [270,271]; indeed, Fusarium spp. have been isolated from a wide range of grasses [270], and a high weed density has been shown to increase FHB disease [272]. Regardless of the positive effects due to a decrease in inoculum, the activity of herbicides such as glyphosate can alter the soil ecosystem through a direct effect on various components of the soil microflora, and can potentially increasing the pathogen population [273]. The effect of weed control with herbicides on Fusarium disease is difficult to predict because a significant increase in disease severity has been associated with the wide-spread application of these chemicals. In particular, herbicides are known to predispose plants to specific diseases [274]. Although largely debated [275], the activity of glyphosate weed control in predisposing plants to Fusarium disease by impairing plant defenses has been demonstrated [276] in both wheat and maize $[277,278]$. However, other studies reported that glyphosate had no significant effect on the FHB index and DON content in wheat and barley [279].

\subsection{Irrigation and Fertilization Regimes}

Drought and heat stress can influence Fusarium disease occurrence and mycotoxin production, with particular emphasis about fumonisin in maize due to prolonged drought conditions. Wheat and small cereals are subjected to few events of heat and drought in their cultivation areas; however, because irrigation can be required, an increment in FHB severity can represent a collateral effect of the increased moisture [280]. Therefore, when irrigation is required, it should be avoided during anthesis and early grain filling periods [281] especially with regard to DON and ZEA accumulation [282]. In contrast, maize, which requires a higher temperature, frequently encounters these abiotic stress conditions. The mitigation of drought stress by irrigation improves maize yield performance [221] and irrigation has been reported to reduce $F$. verticillioides infection and fumonisin accumulation in maize [283], anyway, some authors did not report significant effects after irrigation treatment [221]. The benefit derived from this practice could be lost due to incorrect irrigation methods: in fact, maize fields irrigated by overhead sprinklers showed significantly higher levels of fungal colonization and fumonisin contamination compared with those that were not irrigated or were surface irrigated [184]. Nevertheless, the effect of the irrigation system on fungal colonization and mycotoxin accumulation is debated and typically, no significant influence due to the water supply system is reported [284]. Possible explanations for these results include the following: irrigation treatments were carried 
out in the absence of real drought conditions, other types of stress masked the drought effect, and environmental factors were unfavourable to Fusarium development.

Some evidence indicates that FHB can be influenced by fertilization regimes; in this respect, it was reported that FHB infection and DON contamination may be directly correlated with an increase in nitrogen fertilization [285], and this could be attributed to a state of physiological stress of crop plants and to the alteration of the crop canopy structure [286]. Variable responses to nitrogen fertilization were reported for maize, where the Fusarium mycotoxin concentration was affected differently by the different fertilization regimes [287]. Not only nitrogen but also the availability of micronutrients strongly affect plant growth, resistance to pathogens and stress responses [288] and can predispose plants to diseases as observed for magnesium deficiencies [289].

\subsection{Insect Management}

An important source of Fusarium inoculum is related to the activity of insects, and Fusarium species have been isolated from a wide range of insects [290]. In small cereals, aphids are important insect-pests often correlated with FHB severity, but the efficacy of insecticide application seems strongly related to pest pressure. While, prophylactic sprays with insecticides will not enhanced wheat yields in absence of high pest pressure [291], in Indian trials the application at heading significantly improved FHB control, but no data were collected on mycotoxin [292]. Further, in Northern Europe the use of insecticides in cereals showed a low effect, although significant, with the infestation by $F$. graminearum and the consequent mycotoxins [286].

In maize, phytophagous insects represent one of the more important infection pathways for F. verticillioides infection and consequently, fumonisin contamination. Bt-maize, as well as insecticide treatment, can decrease FER occurrence by reducing potential inoculum infection and fumonisin accumulation [265]. Due to the role of insects in FER infection, a correlation between the borer control and the reduction in Fusarium-mycotoxin levels (trichothecenes, fumonisins, zearalenone and moniliformin) was observed under average climatic conditions [188,293], however no significant differences were observed between different insecticides [294,295]. Recent studies suggested a correlation between ECB and the emerging toxins produced by Fusarium sp. of the section Liseola (beauvericin, fusaproliferin, fusaric acid and moniliformin); therefore it is presumable suppose a positive effect of the borer control to reduce these toxins [208]. Finally, being insects a lesser pathway for $F$. graminearum infection, insecticides treatments are usually ineffective on GER incidence, however, there are evidences that a reduction can occur, albeit to a lesser extent, in DON contamination [296].

\subsection{Chemical and Biological Control}

Among the direct control strategies, a broad range of chemicals was assayed against Fusarium diseases. Fungicidal treatment applied to small cereals against FHB, at least until anthesis or a few days after anthesis [297], is the agricultural practice that has the greatest benefit for grain yield due to a decrease in disease severity and because of the maintenance of good photosynthetic performance of the cereal crops during grain filling [298]. Azole-group fungicides include metconazole, propiconazole, prothioconazole and tebuconazole that belong to the class of demethylation inhibitors. Significant differences between active ingredients were found [299], probably due to the differential sensitivity of different Fusarium species to treatment [300], as well as the tolerance of specific pathogenic strains. Further, crop hybrids exhibit significantly different responses to fungicide treatment [301] and evidences suggest the need of an integrated approach [302]. Azole-group fungicides are the most effective in controlling Fusarium spp. reducing DON, emergent toxins and fumonisin levels in wheat and maize grain, respectively $[301,303,304]$. These fungicides tested in vitro minimized T-2 and HT-2 contamination of oats by F. langsethiae [305], but there was no significant difference in field trials conducted for spring and winter oat varieties [306]. Although these fungicides counteract FHB and trichothecenes, they do not provide complete control. Not-significant reduction or opposite results 
were observed with regard to ZEA [282,304] and often their efficacy was strongly influenced by disease pressure [235,304].

Although fungicides can be exploited for disease reduction, the application of fungicides in some cases resulted in a significant increase in mycotoxin contamination as observed with DON [307]. This effect was probably related to an increase in Fusarium infection due to the activity of the fungicidal molecules on the other microorganisms present within the wheat ear rather than to a direct effect on mycotoxin production [308]. Nonetheless, evidences indicate that fungal exposure to sub-lethal fungicide concentrations can stimulate mycotoxin production and this aspect should be of great concern in cereal cultivation [309]. In fact, some of these molecules are known to trigger oxidative stress, which promotes mycotoxin biosynthesis in F. graminearum and upregulates gene expression in F. verticillioides [310]. For this reason it is conceivable to assume that a reduction in fungal inoculum, after the application of a fungicide, could not always correspond to a reduction in mycotoxin contamination.

Another strategy to control Fusarium spp. colonization and mycotoxin contamination in cereal crops is based on the application of biological control agents (BCAs) and bioactive plant metabolites, which can help to reduce the use of fungicides. Although BCAs may also prove useful in limiting the survival of pathogenic fungi on cereal residues [311], the main target is the control of infection to reduce mycotoxins. In cereal, the most common modes of action of BCAs on cereal spikes include competition for nutrients, the production of antifungal metabolites and the induction of defense responses [312]. The main bacteria with antagonistic abilities against Fusarium include Bacillus, Paenibacillus, Pseudomonas and Streptomyces spp. [313-316]; about fungi, Clonostachys and Trichoderma spp are considered important beneficial antagonist able to counteract mycotoxigenic Fusarium [317-319]. Trichoderma spp. are probably the most effective fungal BCAs and several studies demonstrated their protective effect and the ability to induce systemic resistance, as reported in wheat against $F$. culmorum and maize against $F$. verticillioides $[320,321]$ associated to the reduction in mycotoxin levels.

A further approach is the potential use of bioactive metabolites such as natural antioxidants and phenolic compounds. Some antioxidants are characterized by effects growth and toxin production in the main mycotoxigenic fungi, including Fusarium spp. [322]. The in vitro identification of compounds capable of limiting the pathogenic and mycotoxigenic potential of Fusarium spp. has been demonstrated against species involved in FHB [322,323] and ear rots [324,325] both with antioxidants, phenolic chemicals or essential oils. However, bioactive compound are generally susceptible to degradation promoted by heat, metals, oxygen, light and free radicals [326], therefore the complexation in a stabilizing molecules, such as $\beta$-cyclodextrin [327], could improve the application of this substances against plant pathogen in field.

\section{Conclusions}

Fusarium disease occurs in cereals when plants, fungal pathogens and environmental conditions are conducive for infection. Fusarium disease incidence under similar environmental and conductive conditions is related to the abundance of inoculum present, such as environmental inoculum (soil and airborne), infected crop debris, weeds and phytophagous insects. While airborne inoculum is difficult to predict, Fusarium inoculum on crop debris and weeds, and infections in damaged tissue induced by insects can be reduced. Environmental conditions that favour crop susceptibility to pathogens can be prevented or mitigated through the use of correct crop management practices. GAPs are used in farm and orchard production systems to guarantee food safety, i.e., to ensure that foodstuffs are free of contamination caused by harmful compounds. The full application of GAPs towards toxigenic Fusarium species requires an integrated approach to manage all the possible risk factors to prevent mycotoxin contamination. It is difficult to evaluate or predict the contribution of direct and indirect stress factors on Fusarium disease and mycotoxin occurrence, mainly because of the differential ability of the players (plants and pathogens) to perceive the physiological or environmental changes as 
condition of stress; this is further complicated by specific responses of strains and cultivars of the same species. The complexity of these issues therefore makes it necessary to consider an integrated approach for Fusarium control in cereals by exploiting practices that, on the one hand avoid conditions that can promote plant infection, on the other hand preserve the wellbeing of the plant through stress mitigation.

Acknowledgments: This work was supported by research project DIFMIC.

Author Contributions: D.F. and A.R. wrote the review, R.C. wrote and supervised the review.

Conflicts of Interest: The authors declare no conflict of interest.

\section{References}

1. Logrieco, A.; Mulè, G.; Moretti, A.; Bottalico, A. Toxigenic Fusarium species and mycotoxins associated with maize Ear Rot in Europe. Eur. J. Plant Pathol. 2002, 108, 597-609. [CrossRef]

2. Van der Lee, T.; Zhang, H.; van Diepeningen, A.; Waalwijk, C. Biogeography of Fusarium graminearum species complex and chemotypes: A review. Food Addit. Contam. A 2015, 32, 453-460. [CrossRef] [PubMed]

3. Placinta, C.; D'Mello, J.P.; Macdonald, A.M. A review of worldwide contamination of cereal grains and animal feed with Fusarium mycotoxins. Anim. Feed Sci. Technol. 1999, 78, 21-37. [CrossRef]

4. Nganje, W.E.; Bangsund, D.A.; Leistritz, F.L.; Wilson, W.W.; Tiapo, N.M. Regional economic impacts of Fusarium Head Blight in wheat and barley. Appl. Econ. Perspect. Policy 2004, 26, 332-347. [CrossRef]

5. Munkvold, G.P. Epidemiology of Fusarium diseases and their mycotoxins in maize ears. Eur. J. Plant Pathol. 2003, 109, 705-713. [CrossRef]

6. Logrieco, A.; Moretti, A.; Perrone, G.; Mulè, G. Biodiversity of complexes of mycotoxigenic fungal species associated with Fusarium ear rot of maize and Aspergillus rot of grape. Int. J. Food Microbiol. 2007, 119, 11-16. [CrossRef] [PubMed]

7. Köhl, J.; De Haas, B.H.; Kastelein, P.; Burgers, S.; Waalwijk, C. Population dynamics of Fusarium spp. and Microdochium nivale in crops and crop residues of winter wheat. Phytopathology 2007, 97, 971-978. [CrossRef] [PubMed]

8. Xu, X.-M.; Nicholson, P.; Thomsett, M.A.; Simpson, D.; Cooke, B.M.; Doohan, F.M.; Brennan, J.; Monaghan, S.; Moretti, A.; Mule, G.; et al. Relationship between the fungal complex causing Fusarium head blight of wheat and environmental conditions. Phytopathology 2008, 98, 69-78. [CrossRef] [PubMed]

9. Parry, D.W.; Jenkinson, P.; McLeod, L. Fusarium ear blight (scab) in small grain cereals-A review. Plant Pathol. 1995, 44, 207-238. [CrossRef]

10. Backhouse, D. Global distribution of Fusarium graminearum, F. asiaticum and F. boothii from wheat in relation to climate. Eur. J. Plant Pathol. 2014, 139, 161-173. [CrossRef]

11. Yli-Mattila, T. Ecology and evolution of toxigenic Fusarium species in cereals in Northern Europe and Asia. J. Plant Pathol. 2010, 92, 7-18.

12. Aoki, T.; Ward, T.J.; Kistler, H.C.; O'donnell, K. Systematics, phylogeny and trichothecene mycotoxin potential of Fusarium head blight cereal pathogens. JSM Mycotoxins 2012, 62, 91-102. [CrossRef]

13. Goswami, R.S.; Kistler, H.C. Heading for disaster: Fusarium graminearum on cereal crops. Mol. Plant Pathol. 2004, 5, 515-525. [CrossRef] [PubMed]

14. Osborne, L.E.; Stein, J.M. Epidemiology of Fusarium head blight on small-grain cereals. Int. J. Food Microbiol. 2007, 119, 103-108. [CrossRef] [PubMed]

15. Boutigny, A.-L.; Ward, T.J.; Ballois, N.; Iancu, G.; Ioos, R. Diversity of the Fusarium graminearum species complex on French cereals. Eur. J. Plant Pathol. 2014, 138, 133-148. [CrossRef]

16. McMullen, M.; Bergstrom, G.; De Wolf, E.; Dill-Macky, R.; Hershman, D.; Shaner, G.; Van Sanford, D. A unified effort to fight an enemy of wheat and barley: Fusarium head blight. Plant Dis. 2012, 96, 1712-1728. [CrossRef]

17. Puri, K.D.; Saucedo, E.S.; Zhong, S. Molecular characterization of Fusarium head blight pathogens sampled from a naturally infected disease nursery used for wheat breeding programs in China. Plant Dis. 2012, 96, 1280-1285. [CrossRef] 
18. Yli-Mattila, T.; Paavanen-Huhtala, S.; Jestoi, M.; Parikka, P.; Hietaniemi, V.; Gagkaeva, T.; Sarlin, T.; Haikara, A.; Laaksonen, S.; Rizzo, A. Real-time PCR detection and quantification of Fusarium poae, F. graminearum, F. sporotrichioides and F. langsethiae in cereal grains in Finland and Russia. Arch. Phytopathol. Plant Prot. 2008, 41, 243-260. [CrossRef]

19. Fredlund, E.; Gidlund, A.; Sulyok, M.; Börjesson, T.; Krska, R.; Olsen, M.; Lindblad, M. Deoxynivalenol and other selected Fusarium toxins in Swedish oats-Occurrence and correlation to specific Fusarium species. Int. J. Food Microbiol. 2013, 167, 276-283. [CrossRef] [PubMed]

20. Stenglein, S.A. Fusarium poae: A pathogen that needs more attention. J. Plant Pathol. 2009, 91, 25-36.

21. Bottalico, A.; Perrone, G. Toxigenic Fusarium species and mycotoxins ssociated with Head Blight in small-grain cereals in Europe. Eur. J. Plant Pathol. 2002, 108, 611-624. [CrossRef]

22. Covarelli, L.; Stifano, S.; Beccari, G.; Raggi, L.; Lattanzio, V.M.T.; Albertini, E. Characterization of Fusarium verticillioides strains isolated from maize in Italy: Fumonisin production, pathogenicity and genetic variability. Food Microbiol. 2012, 31, 17-24. [CrossRef] [PubMed]

23. Gatch, E.W.; Munkvold, G.P. Fungal species composition in maize stalks in relation to European corn borer injury and transgenic insect protection. Plant Dis. 2002, 86, 1156-1162. [CrossRef]

24. Parsons, M.W.; Munkvold, G.P. Associations of planting date, drought stress, and insects with Fusarium ear rot and fumonisin B1 contamination in California maize. Food Addit. Contam. A 2010, 27, 591-607. [CrossRef] [PubMed]

25. Duncan, K.E.; Howard, R.J. Biology of maize kernel infection by Fusarium verticillioides. Mol. Plant. Microbe Interact. 2010, 23, 6-16. [CrossRef] [PubMed]

26. Oldenburg, E.; Ellner, F. Distribution of disease symptoms and mycotoxins in maize ears infected by Fusarium culmorum and Fusarium graminearum. Mycotoxin Res. 2015, 31, 117-126. [CrossRef] [PubMed]

27. Miller, J.D. Factors that affect the occurrence of fumonisin. Environ. Health Perspect. 2001, 109, 321-324. [CrossRef] [PubMed]

28. Kebebe, A.Z.; Reid, L.M.; Zhu, X.; Wu, J.; Woldemariam, T.; Voloaca, C.; Xiang, K. Relationship between kernel drydown rate and resistance to gibberella ear rot in maize. Euphytica 2015, 201, 79-88. [CrossRef]

29. Munkvold, G.P.; Desjardins, A.E. Fumonisins in maize: Can we reduce their occurrence? Plant Dis. 1997, 81, 556-565. [CrossRef]

30. Parsons, M.W.; Munkvold, G.P. Effects of planting date and environmental factors on Fusarium ear rot symptoms and fumonisin B1 accumulation in maize grown in six North American locations. Plant Pathol. 2012, 61, 1130-1142. [CrossRef]

31. Balconi, C.; Berardo, N.; Locatelli, S.; Lanzanova, C.; Torri, A.; Redaelli, R. Evaluation of ear rot (Fusarium verticillioides) resistance and fumonisin accumulation in Italian maize inbred lines. Phytopathol. Mediterr. 2014, 53, 14-26.

32. Cao, A.; Santiago, R.; Ramos, A.J.; Souto, X.C.; Aguín, O.; Malvar, R.A.; Butrón, A. Critical environmental and genotypic factors for Fusarium verticillioides infection, fungal growth and fumonisin contamination in maize grown in northwestern Spain. Int. J. Food Microbiol. 2014, 177, 63-71. [CrossRef] [PubMed]

33. Fandohan, P.; Hell, K.; Marasas, W.F.O.; Wingfield, M.J. Infection of maize by Fusarium species and contamination with fumonisin in Africa. Afr. J. Biotechnol. 2003, 2, 570-579.

34. Mohammadi, A.; Shams-Ghahfarokhi, M.; Nazarian-Firouzabadi, F.; Kachuei, R.; Gholami-Shabani, M.; Razzaghi-Abyaneh, M. Gibberella fujikuroi species complex isolated from maize and wheat in Iran: Distribution, molecular identification and fumonisin B1 in vitro biosynthesis. J. Sci. Food Agric. 2016, 96, 1333-1340. [CrossRef] [PubMed]

35. Jurjevic, Z.; Wilson, D.M.; Wilson, J.P.; Geiser, D.M.; Juba, J.H.; Mubatanhema, W.; Widstrom, N.W.; Rains, G.C. Fusarium species of the Gibberella fujikuroi complex and fumonisin contamination of pearl millet and corn in Georgia, USA. Mycopathologia 2005, 159, 401-406. [CrossRef] [PubMed]

36. Stumpf, R.; dos Santos, J.; Gomes, L.B.; Silva, C.N.; Tessmann, D.J.; Ferreira, F.D.; Machinski Junior, M.; Del Ponte, E.M. Fusarium species and fumonisins associated with maize kernels produced in Rio Grande do Sul State for the 2008/09 and 2009/10 growing seasons. Braz. J. Microbiol. 2013, 44, 89-95.

37. Bottalico, A. Fusarium diseases of cereals: Species complex and related mycotoxin profiles, in Europe. J. Plant Pathol. 1998, 80, 85-103.

38. Vigier, B.; Reid, L.M.; Seifert, K.A.; Stewart, D.W.; Hamilton, R.I. Distribution and prediction of Fusarium species associated with maize ear rot in Ontario. Can. J. Plant Pathol. 1997, 19, 60-65. [CrossRef] 
39. Iglesias, J.; Presello, D.A.; Botta, G.; Lori, G.A.; Fauguel, C.M. Aggressiveness of Fusarium section Liseola isolates causing maize ear rot in Argentina. J. Plant Pathol. 2010, 92, 205-211.

40. Wit, M.; Warzecha, R.; Mirzwa-Mroz, E.; Jabionska, E.; Ochodzki, P.; Waskiewicz, A.; Wakulinski, W. Susceptibility of flint and dent maize ears to Fusarium species. Phytopathologia 2011, 60, 35-45.

41. Thrane, U.; Adler, A.; Clasen, P.-E.; Galvano, F.; Langseth, W.; Lew, H.; Logrieco, A.; Nielsen, K.F.; Ritieni, A. Diversity in metabolite production by Fusarium langsethiae, Fusarium poae, and Fusarium sporotrichioides. Int. J. Food Microbiol. 2004, 95, 257-266. [CrossRef] [PubMed]

42. Kokkonen, M.; Ojala, L.; Parikka, P.; Jestoi, M. Mycotoxin production of selected Fusarium species at different culture conditions. Int. J. Food Microbiol. 2010, 143, 17-25. [CrossRef] [PubMed]

43. Sewram, V.; Mshicileli, N.; Shephard, G.S.; Vismer, H.F.; Rheeder, J.P.; Lee, Y.-W.; Leslie, J.F.; Marasas, W.F.O. Production of fumonisin B and C analogues by several Fusarium species. J. Agric. Food Chem. 2005, 53, 4861-4866. [CrossRef] [PubMed]

44. Varga, E.; Wiesenberger, G.; Hametner, C.; Ward, T.J.; Dong, Y.; Schöfbeck, D.; McCormick, S.; Broz, K.; Stückler, R.; Schuhmacher, R.; et al. New tricks of an old enemy: Isolates of Fusarium graminearum produce a type A trichothecene mycotoxin. Environ. Microbiol. 2015, 17, 2588-2600. [CrossRef] [PubMed]

45. Jestoi, M. Emerging Fusarium mycotoxins fusaproliferin, beauvericin, enniatins, and moniliformin-A review. Crit. Rev. Food Sci. Nutr. 2008, 48, 21-49. [CrossRef] [PubMed]

46. Garrido, C.E.; Hernández Pezzani, C.; Pacin, A. Mycotoxins occurrence in Argentina's maize (Zea mays L.), from 1999 to 2010. Food Control 2012, 25, 660-665. [CrossRef]

47. Tralamazza, S.M.; Bemvenuti, R.H.; Zorzete, P.; de Souza Garcia, F.; Corrêa, B. Fungal diversity and natural occurrence of deoxynivalenol and zearalenone in freshly harvested wheat grains from Brazil. Food Chem. 2016, 196, 445-450. [CrossRef] [PubMed]

48. Tittlemier, S.A.; Roscoe, M.; Trelka, R.; Gaba, D.; Chan, J.M.; Patrick, S.K.; Sulyok, M.; Krska, R.; McKendry, T.; Gräfenhan, T. Fusarium damage in small cereal grains from Western Canada. 2. Occurrence of Fusarium toxins and their source organisms in durum wheat harvested in 2010. J. Agric. Food Chem. 2013, 61, 5438-5448. [CrossRef] [PubMed]

49. Han, Z.; Nie, D.; Ediage, E.N.; Yang, X.; Wang, J.; Chen, B.; Li, S.; On, S.L.W.; De Saeger, S.; Wu, A. Cumulative health risk assessment of co-occurring mycotoxins of deoxynivalenol and its acetyl derivatives in wheat and maize: Case study, Shanghai, China. Food Chem. Toxicol. 2014, 74, 334-342. [CrossRef] [PubMed]

50. Liu, Y.; Lu, Y.; Wang, L.; Chang, F.; Yang, L. Occurrence of deoxynivalenol in wheat, Hebei Province, China. Food Chem. B 2016, 197, 1271-1274. [CrossRef] [PubMed]

51. Pleadin, J.; Vahčić, N.; Perši, N.; Ševelj, D.; Markov, K.; Frece, J. Fusarium mycotoxins' occurrence in cereals harvested from Croatian fields. Food Control 2013, 32, 49-54. [CrossRef]

52. Nathanail, A.V.; Syvähuoko, J.; Malachová, A.; Jestoi, M.; Varga, E.; Michlmayr, H.; Adam, G.; Sieviläinen, E.; Berthiller, F.; Peltonen, K. Simultaneous determination of major type A and B trichothecenes, zearalenone and certain modified metabolites in Finnish cereal grains with a novel liquid chromatography-tandem mass spectrometric method. Anal. Bioanal. Chem. 2015, 407, 4745-4755. [CrossRef] [PubMed]

53. Aureli, G.; Amoriello, T.; Belocchi, A.; D’Egidio, M.G.; Fornara, M.; Melloni, S.; Quaranta, F. Preliminary survey on the co-occurrence of DON and T2+HT2 toxins in durum wheat in Italy. Cereal Res. Commun. 2015, 43, 1-11. [CrossRef]

54. Leggieri, M.C.; Bertuzzi, T.; Pietri, A.; Battilani, P. Mycotoxin occurrence in maize produced in Northern Italy over the years 2009-2011: Focus on the role of crop related factors. Phytopathol. Mediterr. 2015, 54, 212-221.

55. Blesa, J.; Moltó, J.-C.; El Akhdari, S.; Mañes, J.; Zinedine, A. Simultaneous determination of Fusarium mycotoxins in wheat grain from Morocco by liquid chromatography coupled to triple quadrupole mass spectrometry. Food Control 2014, 46, 1-5. [CrossRef]

56. Czembor, E.; Stępień, Ł.; Waśkiewicz, A. Effect of environmental factors on Fusarium species and associated mycotoxins in maize grain grown in Poland. PLoS ONE 2015, 10, e0133644. [CrossRef] [PubMed]

57. Lindblad, M.; Gidlund, A.; Sulyok, M.; Börjesson, T.; Krska, R.; Olsen, M.; Fredlund, E. Deoxynivalenol and other selected Fusarium toxins in Swedish wheat-Occurrence and correlation to specific Fusarium species. Int. J. Food Microbiol. 2013, 167, 284-291. [CrossRef] [PubMed]

58. Alkadri, D.; Rubert, J.; Prodi, A.; Pisi, A.; Mañes, J.; Soler, C. Natural co-occurrence of mycotoxins in wheat grains from Italy and Syria. Food Chem. 2014, 157, 111-118. [CrossRef] [PubMed] 
59. Kamala, A.; Ortiz, J.; Kimanya, M.; Haesaert, G.; Donoso, S.; Tiisekwa, B.; De Meulenaer, B. Multiple mycotoxin co-occurrence in maize grown in three agro-ecological zones of Tanzania. Food Control 2015, 54, 208-215. [CrossRef]

60. Xu, X.; Madden, L.V.; Edwards, S.G. Modeling the effects of environmental conditions on HT2 and T2 toxin accumulation in field oat grains. Phytopathology 2014, 104, 57-66. [CrossRef] [PubMed]

61. Ji, F.; Xu, J.; Liu, X.; Yin, X.; Shi, J. Natural occurrence of deoxynivalenol and zearalenone in wheat from Jiangsu province, China. Food Chem. 2014, 157, 393-397. [CrossRef] [PubMed]

62. Nooh, A.; Amra, H.; Youssef, M.M.; El-Banna, A.A. Mycotoxins and toxigenic fungi occurrence in Egyptian maize. Int. J. Adv. Res. 2014, 2, 521-532.

63. Zaied, C.; Zouaoui, N.; Bacha, H.; Abid, S. Natural occurrence of zearalenone in Tunisian wheat grains. Food Control 2012, 25, 773-777. [CrossRef]

64. Cendoya, E.; Monge, M.P.; Palacios, S.A.; Chiacchiera, S.M.; Torres, A.M.; Farnochi, M.C.; Ramirez, M.L. Fumonisin occurrence in naturally contaminated wheat grain harvested in Argentina. Food Control 2014, 37, 56-61. [CrossRef]

65. Peluque, E.; Neres, N.B.; Michelin, E.C.; Reis, T.A.; Rosim, R.E.; Oliveira, C.A.F.; Sousa, R.L.M.; Corrêa, B.; Fernandes, A.M. Fumonisin B1 in cereal mixtures marketed in Brazil. Food Addit. Contam. B 2014, 7, 46-48. [CrossRef] [PubMed]

66. Scussel, V.M.; Savi, G.D.; Costas, L.L.F.; Xavier, J.J.M.; Manfio, D.; Bittencourt, K.O.; Aguiar, K.; Stein, S.M. Fumonisins in corn (Zea mays L.) from Southern Brazil. Food Addit. Contam. B 2014, 7, 151-155. [CrossRef] [PubMed]

67. Li, R.; Tao, B.; Pang, M.; Liu, Y.; Dong, J. Natural occurrence of fumonisins B1 and B2 in maize from three main maize-producing provinces in China. Food Control 2015, 50, 838-842. [CrossRef]

68. Li, F.; Jiang, D.; Zheng, F.; Chen, J.; Li, W. Fumonisins B1, B2 and B3 in corn products, wheat flour and corn oil marketed in Shandong province of China. Food Addit. Contam. B 2015, 8, 169-174. [CrossRef] [PubMed]

69. Torres, O.; Matute, J.; Gelineau-van Waes, J.; Maddox, J.R.; Gregory, S.G.; Ashley-Koch, A.E.; Showker, J.L.; Voss, K.A.; Riley, R.T. Human health implications from co-exposure to aflatoxins and fumonisins in maize-based foods in Latin America: Guatemala as a case study. World Mycotoxin J. 2014, 8, 143-159. [CrossRef]

70. Van Rensburg, B.J.; McLaren, N.W.; Flett, B.C.; Schoeman, A. Fumonisin producing Fusarium spp. and fumonisin contamination in commercial South African maize. Eur. J. Plant Pathol. 2015, 141, 491-504. [CrossRef]

71. Shank, R.A.; Foroud, N.A.; Hazendonk, P.; Eudes, F.; Blackwell, B.A. Current and future experimental strategies for structural analysis of trichothecene mycotoxins-A prospectus. Toxins 2011, 3, 1518-1553. [CrossRef] [PubMed]

72. Koch, P. State of the art of trichothecenes analysis. Toxicol. Lett. 2004, 153, 109-112. [CrossRef] [PubMed]

73. Abbas, H.K.; Yoshizawa, T.; Shier, W.T. Cytotoxicity and phytotoxicity of trichothecene mycotoxins produced by Fusarium spp. Toxicon 2013, 74, 68-75. [CrossRef] [PubMed]

74. Kelly, A.C.; Clear, R.M.; O’Donnell, K.; McCormick, S.; Turkington, T.K.; Tekauz, A.; Gilbert, J.; Kistler, H.C.; Busman, M.; Ward, T.J. Diversity of Fusarium head blight populations and trichothecene toxin types reveals regional differences in pathogen composition and temporal dynamics. Fungal Genet. Biol. 2015, 82, $22-31$. [CrossRef] [PubMed]

75. Ward, T.J.; Clear, R.M.; Rooney, A.P.; O’Donnell, K.; Gaba, D.; Patrick, S.; Starkey, D.E.; Gilbert, J.; Geiser, D.M.; Nowicki, T.W. An adaptive evolutionary shift in Fusarium head blight pathogen populations is driving the rapid spread of more toxigenic Fusarium graminearum in North America. Fungal Genet. Biol. 2008, 45, 473-484. [CrossRef] [PubMed]

76. Gale, L.R.; Harrison, S.A.; Ward, T.J.; O’Donnell, K.; Milus, E.A.; Gale, S.W.; Kistler, H.C. Nivalenol-type populations of Fusarium graminearum and F. asiaticum are prevalent on wheat in Southern Louisiana. Phytopathology 2011, 101, 124-134. [CrossRef] [PubMed]

77. Streit, E.; Naehrer, K.; Rodrigues, I.; Schatzmayr, G. Mycotoxin occurrence in feed and feed raw materials worldwide: Long-term analysis with special focus on Europe and Asia. J. Sci. Food Agric. 2013, 93, 2892-2899. [CrossRef] [PubMed] 
78. European Food Safety Authority. Opinion of the Scientific Panel on contaminants in the food chain [CONTAM] related to Deoxynivalenol (DON) as undesirable substance in animal feed. EFSA J. 2004, $73,1-42$.

79. Cortinovis, C.; Caloni, F.; Schreiber, N.B.; Spicer, L.J. Effects of fumonisin B1 alone and combined with deoxynivalenol or zearalenone on porcine granulosa cell proliferation and steroid production. Theriogenology 2014, 81, 1042-1049. [CrossRef] [PubMed]

80. Pizzo, F.; Caloni, F.; Schutz, L.F.; Totty, M.L.; Spicer, L.J. Individual and combined effects of deoxynivalenol and $\alpha$-zearalenol on cell proliferation and steroidogenesis of granulosa cells in cattle. Environ. Toxicol. Pharmacol. 2015, 40, 722-728. [CrossRef] [PubMed]

81. Covarelli, L.; Beccari, G.; Prodi, A.; Generotti, S.; Etruschi, F.; Juan, C.; Ferrer, E.; Mañes, J. Fusarium species, chemotype characterisation and trichothecene contamination of durum and soft wheat in an area of central Italy. J. Sci. Food Agric. 2015, 95, 540-551. [CrossRef] [PubMed]

82. Schollenberger, M.; Müller, H.M.; Ernst, K.; Sondermann, S.; Liebscher, M.; Schlecker, C.; Wischer, G.; Drochner, W.; Hartung, K.; Piepho, H.-P. Occurrence and distribution of 13 trichothecene toxins in naturally contaminated maize plants in Germany. Toxins 2012, 4, 778-787. [CrossRef] [PubMed]

83. Wu, W.; Flannery, B.M.; Sugita-Konishi, Y.; Watanabe, M.; Zhang, H.; Pestka, J.J. Comparison of murine anorectic responses to the 8-ketotrichothecenes 3-acetyldeoxynivalenol, 15-acetyldeoxynivalenol, fusarenon $\mathrm{X}$ and nivalenol. Food Chem. Toxicol. 2012, 50, 2056-2061. [CrossRef] [PubMed]

84. European Food Safety Authority. Scientific opinion on risks for animal and public health related to the presence of nivalenol in food and feed. EFSA J. 2013, 11. [CrossRef]

85. Alassane-Kpembi, I.; Puel, O.; Oswald, I.P. Toxicological interactions between the mycotoxins deoxynivalenol, nivalenol and their acetylated derivatives in intestinal epithelial cells. Arch. Toxicol. 2014, 89, 1337-1346. [CrossRef] [PubMed]

86. Haratian, M.; Sharifnabi, B.; Alizadeh, A.; Safaie, N. PCR analysis of the Tri13 gene to determine the genetic potential of Fusarium graminearum isolates from Iran to produce nivalenol and deoxynivalenol. Mycopathologia 2008, 166, 109-116. [CrossRef] [PubMed]

87. Beyer, M.; Pogoda, F.; Pallez, M.; Lazic, J.; Hoffmann, L.; Pasquali, M. Evidence for a reversible drought induced shift in the species composition of mycotoxin producing Fusarium head blight pathogens isolated from symptomatic wheat heads. Int. J. Food Microbiol. 2014, 182-183, 51-56. [CrossRef] [PubMed]

88. Fels-Klerx, H.J.V.D.; Klemsdal, S.; Hietaniemi, V.; Lindblad, M.; Ioannou-Kakouri, E.; Asselt, E.D.V. Mycotoxin contamination of cereal grain commodities in relation to climate in North West Europe. Food Addit. Contam. A 2012, 29, 1581-1592. [CrossRef] [PubMed]

89. European Commission. Commission Regulation (EC) No. 1126/2007 on maximum levels for certain contaminants in foodstuffs as regards Fusarium toxins in maize and maize products. Off. J. Eur. Union 2007, $255,14-17$.

90. Fredlund, E.; Gidlund, A.; Pettersson, H.; Olsen, M.; Börjesson, T. Real-time PCR detection of Fusarium species in Swedish oats and correlation to T-2 and HT-2 toxin content. World Mycotoxin J. 2010, 3, 77-88. [CrossRef]

91. Edwards, S.G.; Imathiu, S.M.; Ray, R.V.; Back, M.; Hare, M.C. Molecular studies to identify the Fusarium species responsible for HT-2 and T-2 mycotoxins in UK oats. Int. J. Food Microbiol. 2012, 156, 168-175. [CrossRef] [PubMed]

92. Schuhmacher-Wolz, U.; Heine, K.; Schneider, K. Report on Toxicity Data on Trichothecene Mycotoxins HT-2 and T-2 Toxins; CT/EFSA/CONTAM/2010/03. Available online: http://www.efsa.europa.eu/en/scdocs/scdoc/ 65e.htm (accessed on 9 April 2016).

93. European Food Safety Authority. Scientific Opinion on the risks for animal and public health related to the presence of T-2 and HT-2 toxin in food and feed. EFSA J. 2011, 9, 1-187.

94. Yang, L.; Yu, Z.; Hou, J.; Deng, Y.; Zhou, Z.; Zhao, Z.; Cui, J. Toxicity and oxidative stress induced by T-2 toxin and HT-2 toxin in broilers and broiler hepatocytes. Food Chem. Toxicol. 2016, 87, 128-137. [CrossRef] [PubMed]

95. Lattanzio, V.M.T.; Ciasca, B.; Haidukowski, M.; Infantino, A.; Visconti, A.; Pascale, M. Mycotoxin profile of Fusarium langsethiae isolated from wheat in Italy: Production of type-A trichothecenes and relevant glucosyl derivatives. J. Mass Spectrom. 2013, 48, 1291-1298. [CrossRef] [PubMed] 
96. Kimura, M.; Tokai, T.; Takahashi-Ando, N.; Ohsato, S.; Fujimura, M. Molecular and genetic studies of Fusarium trichothecene biosynthesis: Pathways, genes, and evolution. Biosci. Biotechnol. Biochem. 2007, 71, 2105-2123. [CrossRef] [PubMed]

97. European Food Safety Authority. Scientific opinion on the risks for public health related to the presence of zearalenone in food. EFSA J. 2011, 9. [CrossRef]

98. Cortinovis, C.; Pizzo, F.; Spicer, L.J.; Caloni, F. Fusarium mycotoxins: Effects on reproductive function in domestic animals-A review. Theriogenology 2013, 80, 557-564. [CrossRef] [PubMed]

99. Glenn, A.E. Mycotoxigenic Fusarium species in animal feed. Anim. Feed Sci. Technol. 2007, 137, $213-240$. [CrossRef]

100. Edwards, S. Zearalenone risk in European wheat. World Mycotoxin J. 2011, 4, 433-438. [CrossRef]

101. Wang, Y.; Liu, S.; Zheng, H.; He, C.; Zhang, H. T-2 toxin, zearalenone and fumonisin B1 in feedstuffs from China. Food Addit. Contam. B 2013, 6, 116-122. [CrossRef] [PubMed]

102. Yazar, S.; Omurtag, G.Z. Fumonisins, trichothecenes and zearalenone in cereals. Int. J. Mol. Sci. 2008, 9, 2062-2090. [CrossRef] [PubMed]

103. Marasas, W.F.O. Fumonisins: History, world-wide occurrence and impact. In Fumonisins in Food; Jackson, L.S., DeVries, J.W., Bullerman, L.B., Eds.; Advances in Experimental Medicine and Biology; Springer: Berlin, Germany, 1996; pp. 1-17.

104. Marín, S.; Magan, N.; Ramos, A.J.; Sanchis, V. Fumonisin-producing strains of Fusarium: A review of their ecophysiology. J. Food Prot. 2004, 67, 1792-1805. [PubMed]

105. Caloni, F.; Cortinovis, C. Effects of fusariotoxins in the equine species. Vet. J. 2010, 186, 157-161. [CrossRef] [PubMed]

106. Garbetta, A.; Debellis, L.; de Girolamo, A.; Schena, R.; Visconti, A.; Minervini, F. Dose-dependent lipid peroxidation induction on ex vivo intestine tracts exposed to chyme samples from fumonisins contaminated corn samples. Toxicol. In Vitro 2015, 29, 1140-1145. [CrossRef] [PubMed]

107. European Food Safety Authority. Opinion of the Scientific Panel on contaminants in the food chain [CONTAM] related to fumonisins as undesirable substances in animal feed. EFSA J. 2005, 235, 1-32.

108. Bartók, T.; Szécsi, Á.; Szekeres, A.; Mesterházy, Á.; Bartók, M. Detection of new fumonisin mycotoxins and fumonisin-like compounds by reversed-phase high-performance liquid chromatography/electrospray ionization ion trap mass spectrometry. Rapid Commun. Mass Spectrom. 2006, 20, 2447-2462. [CrossRef] [PubMed]

109. Bartók, T.; Tölgyesi, L.; Szekeres, A.; Varga, M.; Bartha, R.; Szécsi, Á.; Bartók, M.; Mesterházy, Á. Detection and characterization of twenty-eight isomers of fumonisin B1 (FB1) mycotoxin in a solid rice culture infected with Fusarium verticillioides by reversed-phase high-performance liquid chromatography/electrospray ionization time-of-flight and ion trap mass spectrometry. Rapid Commun. Mass Spectrom. 2010, 24, 35-42. [PubMed]

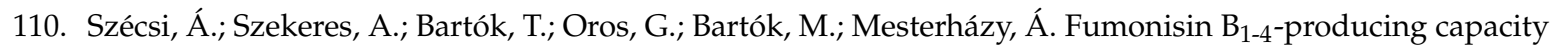
of Hungarian Fusarium verticillioides isolates. World Mycotoxin J. 2010, 3, 67-76. [CrossRef]

111. Gil-Serna, J.; Mateo, E.M.; González-Jaén, M.T.; Jiménez, M.; Vázquez, C.; Patiño, B. Contamination of barley seeds with Fusarium species and their toxins in Spain: An integrated approach. Food Addit. Contam. A 2013, 30, 372-380. [CrossRef] [PubMed]

112. Fotso, J.; Leslie, J.F.; Smith, J.S. Production of beauvericin, moniliformin, fusaproliferin, and fumonisins B1, B2, and B3 by fifteen ex-type strains of Fusarium species. Appl. Environ. Microbiol. 2002, 68, 5195-5197. [CrossRef] [PubMed]

113. Santini, A.; Meca, G.; Uhlig, S.; Ritieni, A. Fusaproliferin, beauvericin and enniatins: Occurrence in food-A review. World Mycotoxin J. 2012, 5, 71-81. [CrossRef]

114. European Food Safety Authority. Scientific opinion on the risks to human and animal health related to the presence of beauvericin and enniatins in food and feed. EFSA J. 2014, 12. [CrossRef]

115. Mallebrera, B.; Juan-Garcia, A.; Font, G.; Ruiz, M.-J. Mechanisms of beauvericin toxicity and antioxidant cellular defense. Toxicol. Lett. 2016, 246, 28-34. [CrossRef] [PubMed]

116. Vongvilai, P.; Isaka, M.; Kittakoop, P.; Srikitikulchai, P.; Kongsaeree, P.; Prabpai, S.; Thebtaranonth, Y. Isolation and structure elucidation of enniatins L, M1, M2, and N: Novel hydroxy analogs. Helv. Chim. Acta 2004, 87, 2066-2073. [CrossRef] 
117. Feifel, S.C.; Schmiederer, T.; Hornbogen, T.; Berg, H.; Süssmuth, R.D.; Zocher, R. In vitro synthesis of new enniatins: Probing the $\alpha$-D-hydroxy carboxylic acid binding pocket of the multienzyme enniatin synthetase. ChemBioChem 2007, 8, 1767-1770. [CrossRef] [PubMed]

118. Bolechová, M.; Benešová, K.; Běláková, S.; Čáslavský, J.; Pospíchalová, M.; Mikulíková, R. Determination of seventeen mycotoxins in barley and malt in the Czech Republic. Food Control 2015, 47, 108-113. [CrossRef]

119. Meca, G.; Zinedine, A.; Blesa, J.; Font, G.; Mañes, J. Further data on the presence of Fusarium emerging mycotoxins enniatins, fusaproliferin and beauvericin in cereals available on the Spanish markets. Food Chem. Toxicol. 2010, 48, 1412-1416. [CrossRef] [PubMed]

120. Zinedine, A.; Meca, G.; Mañes, J.; Font, G. Further data on the occurrence of Fusarium emerging mycotoxins enniatins (A, A1, B, B1), fusaproliferin and beauvericin in raw cereals commercialized in Morocco. Food Control 2011, 22, 1-5. [CrossRef]

121. Oueslati, S.; Meca, G.; Mliki, A.; Ghorbel, A.; Mañes, J. Determination of Fusarium mycotoxins enniatins, beauvericin and fusaproliferin in cereals and derived products from Tunisia. Food Control 2011, 22, 1373-1377. [CrossRef]

122. Hietaniemi, V.; Rämö, S.; Yli-Mattila, T.; Jestoi, M.; Peltonen, S.; Kartio, M.; Sieviläinen, E.; Koivisto, T.; Parikka, P. Updated survey of the Fusarium species and toxins in Finnish cereal grains. Food Addit. Contam. A 2016. [CrossRef] [PubMed]

123. Serrano, A.B.; Font, G.; Ruiz, M.J.; Ferrer, E. Co-occurrence and risk assessment of mycotoxins in food and diet from Mediterranean area. Food Chem. 2012, 135, 423-429. [CrossRef] [PubMed]

124. Lee, K.-E.; Kim, B.H.; Lee, C. Occurrence of Fusarium mycotoxin beauvericin in animal feeds in Korea. Anim. Feed Sci. Technol. 2010, 157, 190-194. [CrossRef]

125. Logrieco, A.; Rizzo, A.; Ferracane, R.; Ritieni, A. Occurrence of beauvericin and enniatins in wheat affected by Fusarium avenaceum head blight. Appl. Environ. Microbiol. 2002, 68, 82-85. [CrossRef] [PubMed]

126. Fumero, M.V.; Reynoso, M.M.; Chulze, S. Fusarium temperatum and Fusarium subglutinans isolated from maize in Argentina. Int. J. Food Microbiol. 2015, 199, 86-92. [CrossRef] [PubMed]

127. Blesa, J.; Marín, R.; Lino, C.M.; Mañes, J. Evaluation of enniatins A, A1, B, B1 and beauvericin in Portuguese cereal-based foods. Food Addit. Contam. A 2012, 29, 1727-1735. [CrossRef] [PubMed]

128. Reyes-Velázquez, W.P.; Figueroa-Gómez, R.M.; Barberis, M.; Reynoso, M.M.; Rojo, F.G.A.; Chulze, S.N.; Torres, A.M. Fusarium species (section Liseola) occurrence and natural incidence of beauvericin, fusaproliferin and fumonisins in maize hybrids harvested in Mexico. Mycotoxin Res. 2011, 27, 187-194. [CrossRef] [PubMed]

129. Basílico, M.L.Z.; Pose, G.; Ludemann, V.; Pinto, V.E.F.; Aríngoli, E.E.; Ritieni, A.; Basílico, J.C. Fungal diversity and natural occurrence of fusaproliferin, beauvericin, deoxynivalenol and nivalenol in wheat cultivated in Santa Fe Province, Argentina. Mycotoxin Res. 2010, 26, 85-91. [CrossRef] [PubMed]

130. Moretti, A.; Mulè, G.; Ritieni, A.; Logrieco, A. Further data on the production of beauvericin, enniatins and fusaproliferin and toxicity to Artemia salina by Fusarium species of Gibberella fujikuroi species complex. Int. J. Food Microbiol. 2007, 118, 158-163. [CrossRef] [PubMed]

131. Moretti, A.; Logrieco, A.; Ritieni, A.; Randazzo, G.; Bottalico, A.; Macchia, L. Beauvericin and Fusaproliferin: Emerging Fusarium Toxins; Bulletin of the Institute for Comprehensive Agricultural Sciences, Kinki University; Kinki University: Higashiosaka, Japan, 1998; Volume 6, pp. 13-21.

132. Ritieni, A.; Monti, S.M.; Randazzo, G.; Logrieco, A.; Moretti, A.; Peluso, G.; Ferracane, R.; Fogliano, V. Teratogenic effects of fusaproliferin on chicken embryos. J. Agric. Food Chem. 1997, 45, 3039-3043. [CrossRef]

133. Prosperini, A.; Meca, G.; Font, G.; Ruiz, M.J. Study of the cytotoxic activity of beauvericin and fusaproliferin and bioavailability in vitro on Caco-2 cells. Food Chem. Toxicol. 2012, 50, 2356-2361. [CrossRef] [PubMed]

134. Munkvold, G.; Stahr, H.M.; Logrieco, A.; Moretti, A.; Ritieni, A. Occurrence of fusaproliferin and beauvericin in Fusarium-contaminated livestock feed in Iowa. Appl. Environ. Microbiol. 1998, 64, 3923-3926. [PubMed]

135. Shephard, G.S.; Burger, H.-M.; Gambacorta, L.; Krska, R.; Powers, S.P.; Rheeder, J.P.; Solfrizzo, M.; Sulyok, M.; Visconti, A.; Warth, B.; et al. Mycological analysis and multimycotoxins in maize from rural subsistence farmers in the former Transkei, South Africa. J. Agric. Food Chem. 2013, 61, 8232-8240. [CrossRef] [PubMed]

136. Steyn, M.; Thiel, P.G.; Van Schalkwyk, G.C. Isolation and purification of moniliformin. J.-Assoc. Off. Anal. Chem. 1978, 61, 578-580. [PubMed]

137. Chelkowski, J.; Zawadzki, M.; Zajkowski, P.; Logrieco, A.; Bottalico, A. Moniliformin production by Fusarium species. Mycotoxin Res. 1990, 6, 41-45. [CrossRef] [PubMed] 
138. Thiel, P.G. A molecular mechanism for the toxic action of moniliformin, a mycotoxin produced by Fusarium moniliforme. Biochem. Pharmacol. 1978, 27, 483-486. [CrossRef]

139. Peltonen, K.; Jestoi, M.; Eriksen, G. Health effects of moniliformin: A poorly understood Fusarium mycotoxin. World Mycotoxin J. 2010, 3, 403-414. [CrossRef]

140. Scarpino, V.; Blandino, M.; Negre, M.; Reyneri, A.; Vanara, F. Moniliformin analysis in maize samples from North-West Italy using multifunctional clean-up columns and the LC-MS/MS detection method. Food Addit. Contam. A 2013, 30, 876-884. [CrossRef] [PubMed]

141. Uhlig, S.; Torp, M.; Jarp, J.; Parich, A.; Gutleb, A.C.G.; Krska, R. Moniliformin in Norwegian grain. Food Addit. Contam. 2004, 21, 598-606. [CrossRef] [PubMed]

142. Sørensen, J.L.; Nielsen, K.F.; Thrane, U. Analysis of moniliformin in maize plants using hydrophilic interaction chromatography. J. Agric. Food Chem. 2007, 55, 9764-9768. [CrossRef] [PubMed]

143. Codex Alimentarius Commission. Codex General Standard for Contaminants and Toxins in Food and Feed; CODEX STAN 193-1995 (Rev.1-1997); in Joint FAO/WHO Food Standards Programme; FAO, WHO: Rome, Italy, 2000.

144. Codex Alimentarius Commission. Code of practice for the prevention and reduction of mycotoxin contamination in cereals, including annexes on ochratoxin $\mathrm{A}$, zearalenone, fumonisins and tricothecenes (CAC/RCP 51-2003). In Prevention and Reduction of Food and Feed Contamination; FAO, WHO: Rome, Italy, 2003; pp. 1-13.

145. Van Egmond, H.P.; Schothorst, R.C.; Jonker, M.A. Regulations relating to mycotoxins in food. Anal. Bioanal. Chem. 2007, 389, 147-157. [CrossRef] [PubMed]

146. Codex Alimentarius Commission. Report of the ninth session of the codex committee on contaminants in foods. In Joint FAO/WHO Food Standards Programme; FAO, WHO: New Delhi, India, 2015.

147. Leslie, J.F.; Bandyopadhyay, R.; Visconti, A. Mycotoxins: Detection Methods, Management, Public Health and Agricultural Trade; CABI: Wallingford, UK, 2008.

148. Lee, T.; Lee, S.-H.; Lee, S.-H.; Shin, J.Y.; Yun, J.-C.; Lee, Y.-W.; Ryu, J.-G. Occurrence of Fusarium mycotoxins in rice and its milling by-products in Korea. J. Food Prot. 2011, 74, 1169-1174. [CrossRef] [PubMed]

149. Agência Nacional de Vigilância Sanitária (ANVISA). Resolução RDC $n^{\circ} 7$, de 18 de Fevereiro de 2011. Diário Oficial da União-Seção 1, n 37, 22 de Fevereiro de 2011; ANVISA: Brasília, Brazil, 2011.

150. Health Canada. Canadian Standards (Maximum Limits) for Various Chemical Contaminants in Foods. 2016. Available online: http://www.hc-sc.gc.ca/fn-an/securit/chem-chim/contaminants-guidelines-directiveseng.php (accessed on 9 April 2016).

151. National Health and Family Planning of People's Republic of China (NFHPC). China GB 2761-2011 Maximum Levels of Mycotoxins in Foods. 2011. Available online: http://www.cirs-group.com/food/news/GB_27612011_maximum_levels_mycotoxins.html (accessed on 9 April 2016).

152. Ministry of Health of the Russian Federation. Amendments and Additions No. 18 to Hygienic Requirements for Safety and Nutrition Value of Food Products; 2.3.2.1078-01; Ministry of Health of the Russian Federation: Moscow, Russia, 2010.

153. US Food and Drug Administration (US FDA). Guidance for Industry: Fumonisin Levels in Human Foods and Animal Feeds; Final Guidance. US FDA: Silver Spring, MD, USA, 2001.

154. US Food and Drug Administration (US FDA). Guidance for Industry and FDA: Advisory Levels for Deoxynivalenol (DON) in Finished Wheat Products for Human Consumption and Grains and Grain by-Products Used for Animal Feed; US FDA: Silver Spring, MD, USA, 2010.

155. European Commission. Commission Recommendation (2006/576/CE) on the presence of deoxynivalenol, zearalenone, ochratoxin A, T-2 and HT-2 and fumonisins in products intended for animal feeding. Off. J. Eur. Union 2006, 229, 7-9.

156. European Commission. Commission Recommendation (2013/165/EU) on the presence of T-2 and HT-2 toxin in cereals and cereal products. Off. J. Eur. Union 2013, 91, 12-15.

157. Doohan, F.M.; Brennan, J.; Cooke, B.M. Influence of climatic factors on Fusarium species pathogenic to cereals. In Epidemiology of Mycotoxin Producing Fungi; Springer: Berlin, Germany, 2003; pp. 755-768.

158. Isebaert, S.; de Saeger, S.; Devreese, R.; Verhoeven, R.; Maene, P.; Heremans, B.; Haesaert, G. Mycotoxin-producing Fusarium species occurring in winter wheat in Belgium (Flanders) during 2002-2005. J. Phytopathol. 2009, 157, 108-116. [CrossRef] 
159. Oerke, E.-C.; Meier, A.; Dehne, H.-W.; Sulyok, M.; Krska, R.; Steiner, U. Spatial variability of Fusarium head blight pathogens and associated mycotoxins in wheat crops. Plant Pathol. 2010, 59, 671-682. [CrossRef]

160. Paterson, R.R. M.; Lima, N. How will climate change affect mycotoxins in food? Food Res. Int. 2010, 43, 1902-1914. [CrossRef]

161. Schmidt-Heydt, M.; Parra, R.; Geisen, R.; Magan, N. Modelling the relationship between environmental factors, transcriptional genes and deoxynivalenol mycotoxin production by strains of two Fusarium species. J. R. Soc. Interface 2011, 8, 117-126. [CrossRef] [PubMed]

162. Medina, A.; Schmidt-Heydt, M.; Cárdenas-Chávez, D.L.; Parra, R.; Geisen, R.; Magan, N. Integrating toxin gene expression, growth and fumonisin B1 and B2 production by a strain of Fusarium verticillioides under different environmental factors. J. R. Soc. Interface 2013, 10, 20130320. [CrossRef] [PubMed]

163. Martins, M.L.; Martins, H.M. Influence of water activity, temperature and incubation time on the simultaneous production of deoxynivalenol and zearalenone in corn (Zea mays) by Fusarium graminearum. Food Chem. 2002, 79, 315-318. [CrossRef]

164. Marín, P.; Magan, N.; Vázquez, C.; González-Jaén, M.T. Differential effect of environmental conditions on the growth and regulation of the fumonisin biosynthetic gene FUM1 in the maize pathogens and fumonisin producers Fusarium verticillioides and Fusarium proliferatum. FEMS Microbiol. Ecol. 2010, 73, 303-311. [CrossRef] [PubMed]

165. Uhlig, S.; Eriksen, G.S.; Hofgaard, I.S.; Krska, R.; Beltrán, E.; Sulyok, M. Faces of a changing climate: Semi-quantitative multi-mycotoxin analysis of grain grown in exceptional climatic conditions in Norway. Toxins 2013, 5, 1682-1697. [CrossRef] [PubMed]

166. Miller, J.D.; Savard, M.E.; Schaafsma, A.W. Mycotoxin production by Fusarium moniliforme and Fusarium proliferatum from Ontario and occurrence of fumonisin in the 1993 corn crop. Can. J. Plant Pathol. 1995, 17, 233-239.

167. Picot, A.; Hourcade-Marcolla, D.; Barreau, C.; Pinson-Gadais, L.; Caron, D.; Richard-Forget, F.; Lannou, C. Interactions between Fusarium verticillioides and Fusarium graminearum in maize ears and consequences for fungal development and mycotoxin accumulation. Plant Pathol. 2012, 61, 140-151. [CrossRef]

168. Fitt, B.D.; Huang, Y.-J.; van den Bosch, F.; West, J.S. Coexistence of related pathogen species on arable crops in space and time. Phytopathology 2006, 44, 163-182. [CrossRef] [PubMed]

169. Stachowicz, J.J. Mutualism, facilitation, and the structure of ecological communities positive interactions play a critical, but underappreciated, role in ecological communities by reducing physical or biotic stresses in existing habitats and by creating new habitats on which many species depend. Bioscience 2001, 51, 235-246.

170. Mehl, H.L.; Cotty, P.J. Influence of plant host species on intraspecific competition during infection by Aspergillus flavus. Plant Pathol. 2013, 62, 1310-1318. [CrossRef]

171. Cooney, J.M.; Lauren, D.R.; di Menna, M.E. Impact of competitive fungi on trichothecene production by Fusarium graminearum. J. Agric. Food Chem. 2001, 49, 522-526. [CrossRef] [PubMed]

172. Müller, M.; Steier, I.; Köppen, R.; Siegel, D.; Proske, M.; Korn, U.; Koch, M. Cocultivation of phytopathogenic Fusarium and Alternaria strains affects fungal growth and mycotoxin production. J. Appl. Microbiol. 2012, 113, 874-887. [CrossRef] [PubMed]

173. Xu, X.-M.; Monger, W.; Ritieni, A.; Nicholson, P. Effect of temperature and duration of wetness during initial infection periods on disease development, fungal biomass and mycotoxin concentrations on wheat inoculated with single, or combinations of, Fusarium species. Plant Pathol. 2007, 56, 943-956. [CrossRef]

174. Pan, J.J.; May, G. Fungal-fungal associations affect the assembly of endophyte communities in maize (Zea mays). Microb. Ecol. 2009, 58, 668-678. [CrossRef] [PubMed]

175. Siou, D.; Gélisse, S.; Laval, V.; Suffert, F.; Lannou, C. Mutual exclusion between fungal species of the FHB complex in a wheat spike. Appl. Environ. Microbiol. 2015. [CrossRef] [PubMed]

176. Xu, X.-M.; Parry, D.W.; Nicholson, P.; Thomsett, M.A.; Simpson, D.; Edwards, S.G.; Cooke, B.M.; Doohan, F.M.; Brennan, J.M.; Moretti, A.; et al. Predominance and association of pathogenic fungi causing Fusarium ear blightin wheat in four European countries. Eur. J. Plant Pathol. 2005, 112, 143-154. [CrossRef]

177. Audenaert, K.; Van Broeck, R.; Bekaert, B.; De Witte, F.; Heremans, B.; Messens, K.; Höfte, M.; Haesaert, G. Fusarium head blight (FHB) in Flanders: Population diversity, inter-species associations and DON contamination in commercial winter wheat varieties. Eur. J. Plant Pathol. 2009, 125, 445-458. [CrossRef]

178. Wagacha, J.M.; Oerke, E.-C.; Dehne, H.-W.; Steiner, U. Interactions of Fusarium species during prepenetration development. Fungal Biol. 2012, 116, 836-847. [CrossRef] [PubMed] 
179. Walkowiak, S.; Bonner, C.T.; Wang, L.; Blackwell, B.; Rowland, O.; Subramaniam, R. Intraspecies interaction of Fusarium graminearum contributes to reduced toxin production and virulence. Mol. Plant Microbe Interact. 2015, 28, 1256-1267. [PubMed]

180. Siou, D.; Gélisse, S.; Laval, V.; Elbelt, S.; Repinçay, C.; Bourdat-Deschamps, M.; Suffert, F.; Lannou, C. Interactions between head blight pathogens: Consequences for disease development and toxin production in wheat spikes. Appl. Environ. Microbiol. 2015, 81, 957-965. [CrossRef] [PubMed]

181. Marín, S.; Sanchis, V.; Ramos, A.J.; Vinas, I.; Magan, N. Environmental factors, in vitro interactions, and niche overlap between Fusarium moniliforme, F. proliferatum, and F. graminearum, Aspergillus and Penicillium species from maize grain. Mycol. Res. 1998, 102, 831-837. [CrossRef]

182. Zorzete, P.; Castro, R.S.; Pozzi, C.R.; Israel, A.L.M.; Fonseca, H.; Yanaguibashi, G.; Corrêa, B. Relative populations and toxin production by Aspergillus flavus and Fusarium verticillioides in artificially inoculated corn at various stages of development under field conditions. J. Sci. Food Agric. 2008, 88, 48-55. [CrossRef]

183. Velluti, A.; Marín, S.; Gonzalez, R.; J Ramos, A.; Sanchis, V. Fumonisin B1, zearalenone and deoxynivalenol production by Fusarium moniliforme, F. proliferatum and F. graminearum in mixed cultures on irradiated maize kernels. J. Sci. Food Agric. 2001, 81, 88-94. [CrossRef]

184. Ferrigo, D.; Raiola, A.; Causin, R. Plant stress and mycotoxin accumulation in maize. Agrochimica 2014, 58, 116-127.

185. Etcheverry, M. Aflatoxin B1, zearalenone and deoxynivalenol production by Aspergillus parasiticus and Fusarium graminearum in interactive cultures on irradiated corn kernels. Mycopathologia 1998, 142, 37-42. [CrossRef] [PubMed]

186. Brakhage, A.A. Regulation of fungal secondary metabolism. Nat. Rev. Microbiol. 2013, 11, 21-32. [CrossRef] [PubMed]

187. Bruns, H.A. Controlling aflatoxin and fumonisin in maize by crop management. Toxin Rev. 2003, 22, $153-173$. [CrossRef]

188. Folcher, L.; Jarry, M.; Weissenberger, A.; Gérault, F.; Eychenne, N.; Delos, M.; Regnault-Roger, C. Comparative activity of agrochemical treatments on mycotoxin levels with regard to corn borers and Fusarium mycoflora in maize (Zea mays L.) fields. Crop Prot. 2009, 28, 302-308. [CrossRef]

189. Abbas, H.K.; Zablotowicz, R.M.; Shier, W.T.; Johnson, B.J.; Phillips, N.A.; Weaver, M.A.; Abel, C.A.; Bruns, H.A. Aflatoxin and fumonisin in corn (Zea mays) infected by common smut Ustilago maydis. Plant Dis. 2015, 99, 1236-1240. [CrossRef]

190. Afifi, M.; Swanton, C. Maize seed and stem roots differ in response to neighbouring weeds. Weed Res. 2011, 51, 442-450. [CrossRef]

191. Robertson, A.E.; Munkvold, G.P.; Hurburgh, C.R.; Ensley, S. Effects of natural hail damage on ear rots, mycotoxins, and grain quality characteristics of corn. Agron. J. 2011, 103, 193-199. [CrossRef]

192. Lobell, D.B.; Asner, G.P. Climate and management contributions to recent trends in U.S. agricultural yields. Science 2003, 299. [CrossRef] [PubMed]

193. Cao, A.; Santiago, R.; Ramos, A.J.; Marín, S.; Reid, L.M.; Butrón, A. Environmental factors related to fungal infection and fumonisin accumulation during the development and drying of white maize kernels. Int. J. Food Microbiol. 2013, 164, 15-22. [CrossRef] [PubMed]

194. Zhao, Z.; Chen, G.; Zhang, C. Interaction between reactive oxygen species and nitric oxide in drought-induced abscisic acid synthesis in root tips of wheat seedlings. Funct. Plant Biol. 2001, 28, 1055-1061. [CrossRef]

195. Torres, M.A.; Jones, J.D. G.; Dangl, J.L. Reactive oxygen species signaling in response to pathogens. Plant Physiol. 2006, 141, 373-378. [CrossRef] [PubMed]

196. Sharma, P.; Jha, A.B.; Dubey, R.S.; Pessarakli, M. Reactive oxygen species, oxidative damage, and antioxidative defense mechanism in plants under stressful conditions. J. Bot. 2012, 2012, 217037. [CrossRef]

197. Ponts, N.; Pinson-Gadais, L.; Verdal-Bonnin, M.-N.; Barreau, C.; Richard-Forget, F. Accumulation of deoxynivalenol and its 15-acetylated form is significantly modulated by oxidative stress in liquid cultures of Fusarium graminearum. FEMS Microbiol. Lett. 2006, 258, 102-107. [CrossRef] [PubMed]

198. Ferrigo, D.; Raiola, A.; Bogialli, S.; Bortolini, C.; Tapparo, A.; Causin, R. In vitro production of fumonisins by Fusarium verticillioides under oxidative stress induced by $\mathrm{H}_{2} \mathrm{O}_{2}$. J. Agric. Food Chem. 2015, 63, 4879-4885. [CrossRef] [PubMed] 
199. Avantaggiato, G.; Quaranta, F.; Desiderio, E.; Visconti, A. Fumonisin contamination of maize hybrids visibly damaged by Sesamia. J. Sci. Food Agric. 2003, 83, 13-18. [CrossRef]

200. Kerchev, P.I.; Fenton, B.; Foyer, C.H.; Hancock, R.D. Plant responses to insect herbivory: Interactions between photosynthesis, reactive oxygen species and hormonal signalling pathways. Plant Cell Environ. 2012, 35, 441-453. [CrossRef] [PubMed]

201. Liu, Y.; Walker, F.; Hoeglinger, B.; Buchenauer, H. Solvolysis procedures for the determination of bound residues of the mycotoxin deoxynivalenol in Fusarium species infected grain of two winter wheat cultivars preinfected with barley yellow dwarf virus. J. Agric. Food Chem. 2005, 53, 6864-6869. [CrossRef] [PubMed]

202. De Zutter, N.; Audenaert, K.; Ameye, M.; De Boevre, M.; De Saeger, S.; Haesaert, G.; Smagghe, G. The plant response induced in wheat ears by a combined attack of Sitobion avenae aphids and Fusarium graminearum boosts the fungal infection and its deoxynivalenol production. Mol. Plant Pathol. 2016. [CrossRef] [PubMed]

203. Powell, G.; Tosh, C.R.; Hardie, J. Host plant selection by aphids: Behavioral, evolutionary, and applied perspectives. Annu. Rev. Entomol. 2006, 51, 309-330. [CrossRef] [PubMed]

204. Ponts, N.; Couedelo, L.; Pinson-Gadais, L.; Verdal-Bonnin, M.-N.; Barreau, C.; Richard-Forget, F. Fusarium response to oxidative stress by $\mathrm{H}_{2} \mathrm{O}_{2}$ is trichothecene chemotype-dependent. FEMS Microbiol. Lett. 2009, 293, 255-262. [CrossRef] [PubMed]

205. Desmond, O.J.; Manners, J.M.; Stephens, A.E.; Maclean, D.J.; Schenk, P.M.; Gardiner, D.M.; Munn, A.L.; Kazan, K. The Fusarium mycotoxin deoxynivalenol elicits hydrogen peroxide production, programmed cell death and defence responses in wheat. Mol. Plant Pathol. 2008, 9, 435-445. [CrossRef] [PubMed]

206. Qin, J.; Wang, G.; Jiang, C.; Xu, J.-R.; Wang, C. Fgk3 glycogen synthase kinase is important for development, pathogenesis, and stress responses in Fusarium graminearum. Sci. Rep. 2015, 5, 8504. [CrossRef] [PubMed]

207. Ameye, M.; Audenaert, K.; de Zutter, N.; Steppe, K.; van Meulebroek, L.; Vanhaecke, L.; de Vleesschauwer, D.; Haesaert, G.; Smagghe, G. Priming of wheat with the green leaf volatile Z-3-hexenyl acetate enhances defense against Fusarium graminearum but boosts deoxynivalenol production. Plant Physiol. 2015, 167, 1671-1684. [CrossRef] [PubMed]

208. Blandino, M.; Scarpino, V.; Vanara, F.; Sulyok, M.; Krska, R.; Reyneri, A. Role of the European corn borer (Ostrinia nubilalis) on contamination of maize with 13 Fusarium mycotoxins. Food Addit. Contam. A 2015, 32, 533-543. [CrossRef] [PubMed]

209. Santiago, R.; Cao, A.; Malvar, R.A.; Butrón, A. Is it possible to control fumonisin contamination in maize kernels by using genotypes resistant to the Mediterranean corn borer? J. Econ. Entomol. 2013, 106, 2241-2246. [CrossRef] [PubMed]

210. Scully, B.T.; Krakowsky, M.D.; Ni, X.; Wilson, J.P.; Lee, R.D.; Guo, B.Z. Preharvest aflatoxin contamination of corn and other grain crops grown on the US Southeastern Coastal Plain. Toxin Rev. 2009, 28, 169-179. [CrossRef]

211. Barry, D.; Zuber, M.S.; Lillehoj, E.B.; McMillian, W.W.; Adams, N.J.; Kwolek, W.F.; Widstrom, N.W. Evaluation of two arthropod vectors as inoculators of developing maize ears with Aspergillus flavus. Environ. Entomol. 1985, 14, 634-636. [CrossRef]

212. Bricchi, I.; Leitner, M.; Foti, M.; Mithöfer, A.; Boland, W.; Maffei, M.E. Robotic mechanical wounding (MecWorm) versus herbivore-induced responses: Early signaling and volatile emission in Lima bean (Phaseolus lunatus L.). Planta 2010, 232, 719-729. [CrossRef] [PubMed]

213. Lin, C.-C.; Jih, P.-J.; Lin, H.-H.; Lin, J.-S.; Chang, L.-L.; Shen, Y.-H.; Jeng, S.-T. Nitric oxide activates superoxide dismutase and ascorbate peroxidase to repress the cell death induced by wounding. Plant Mol. Biol. 2011, 77, 235-249. [CrossRef] [PubMed]

214. Ponts, N.; Pinson-Gadais, L.; Barreau, C.; Richard-Forget, F.; Ouellet, T. Exogenous $\mathrm{H}_{2} \mathrm{O}_{2}$ and catalase treatments interfere with Tri genes expression in liquid cultures of Fusarium graminearum. FEBS Lett. 2007, 581, 443-447. [CrossRef] [PubMed]

215. Schaafsma, A.W.; Miller, J.D.; Savard, M.E.; Ewing, R.J. Ear rot development and mycotoxin production in corn in relation to inoculation method, corn hybrid, and species of Fusarium. Can. J. Plant Pathol. 1993, 15, 185-192. [CrossRef]

216. Page, E.R.; Liu, W.; Cerrudo, D.; Lee, E.A.; Swanton, C.J. Shade avoidance influences stress tolerance in maize. Weed Sci. 2011, 59, 326-334. [CrossRef]

217. Hol, W.H.G.; de Boer, W.; ten Hooven, F.; van der Putten, W.H. Competition increases sensitivity of wheat (Triticum aestivum) to biotic plant-soil feedback. PLoS ONE 2013, 8, e66085. [CrossRef] [PubMed] 
218. Ford, K.L.; Cassin, A.; Bacic, A. Quantitative proteomic analysis of wheat cultivars with differing drought stress tolerance. Front. Plant Sci. 2011, 2. [CrossRef] [PubMed]

219. Abbas, H.K.; Williams, W.P.; Windham, G.L.; Pringle, H.C.; Xie, W.; Shier, W.T. Aflatoxin and fumonisin contamination of commercial corn (Zea mays) hybrids in Mississippi. J. Agric. Food Chem. 2002, 50, 5246-5254. [CrossRef] [PubMed]

220. Pascale, M.; Visconti, A.; Chelkowski, J. Ear rot susceptibility and mycotoxin contamination of maize hybrids inoculated with Fusarium species under field conditions. In Mycotoxins in Plant Disease; Springer: Berlin, Germany, 2002; pp. 645-651.

221. Abbas, H.K.; Mascagni, H.J., Jr.; Bruns, H.A.; Shier, W.T. Effect of planting density, irrigation regimes, and maize hybrids with varying ear size on yield, and aflatoxin and fumonisin contamination levels. Am. J. Plant Sci. 2012, 3, 1341-1354. [CrossRef]

222. Teller, R.S.; Schmidt, R.J.; Whitlow, L.W.; Kung, L., Jr. Effect of physical damage to ears of corn before harvest and treatment with various additives on the concentration of mycotoxins, silage fermentation, and aerobic stability of corn silage. J. Dairy Sci. 2012, 95, 1428-1436. [CrossRef] [PubMed]

223. Maffei, M.E.; Mithöfer, A.; Arimura, G.-I.; Uchtenhagen, H.; Bossi, S.; Bertea, C.M.; Cucuzza, L.S.; Novero, M.; Volpe, V.; Quadro, S.; et al. Effects of feeding Spodoptera littoralis on Lima bean leaves. III. Membrane depolarization and involvement of hydrogen peroxide. Plant Physiol. 2006, 140, 1022-1035. [CrossRef] [PubMed]

224. Reyneri, A.; Bruno, G.; D’Egidio, M.G.; Balconi, C. Linee Guida per il Controllo Delle Micotossine Nella Granella di Mais e di Frumento, 2016. Available online: https://www.politicheagricole.it/flex/cm/pages/ ServeBLOB.php/L/IT/IDPagina/9703 (accessed on 9 April 2016). (In Italian)

225. Rossi, V.; Scandolara, A.; Battilani, P. Effect of environmental conditions on spore production by Fusarium verticillioides, the causal agent of maize ear rot. Eur. J. Plant Pathol. 2009, 123, 159-169. [CrossRef]

226. Keller, M.D.; Bergstrom, G.C.; Shields, E.J. The aerobiology of Fusarium graminearum. Aerobiologia 2014, 30, 123-136. [CrossRef]

227. Nicolardot, B.; Bouziri, L.; Bastian, F.; Ranjard, L. A microcosm experiment to evaluate the influence of location and quality of plant residues on residue decomposition and genetic structure of soil microbial communities. Soil Biol. Biochem. 2007, 39, 1631-1644. [CrossRef]

228. Khonga, E.B.; Sutton, J.C. Inoculum production and survival of Gibberella zeae in maize and wheat residues. Can. J. Plant Pathol. 1988, 10, 232-239. [CrossRef]

229. Cotten, T.K.; Munkvold, G.P. Survival of Fusarium moniliforme, F. proliferatum, and F. subglutinans in maize stalk residue. Phytopathology 1998, 88, 550-555. [CrossRef] [PubMed]

230. Sengupta, A.; Dick, W.A. Bacterial community diversity in soil under two tillage practices as determined by pyrosequencing. Microb. Ecol. 2015, 70, 853-859. [CrossRef] [PubMed]

231. Degrune, F.; Theodorakopoulos, N.; Dufrêne, M.; Colinet, G.; Bodson, B.; Hiel, M.-P.; Taminiau, B.; Nezer, C.; Daube, G.; Vandenbol, M. No favorable effect of reduced tillage on microbial community diversity in a silty loam soil (Belgium). Agric. Ecosyst. Environ. 2016, 224, 12-21. [CrossRef]

232. Sipilä, T.P.; Yrjälä, K.; Alakukku, L.; Palojärvi, A. Cross-site soil microbial communities under tillage regimes: Fungistasis and microbial biomarkers. Appl. Environ. Microbiol. 2012, 78, 8191-8201. [CrossRef] [PubMed]

233. Peigné, J.; Messmer, M.; Aveline, A.; Berner, A.; Mäder, P.; Carcea, M.; Narducci, V.; Samson, M.-F.; Thomsen, I.K.; Celette, F.; et al. Wheat yield and quality as influenced by reduced tillage in organic farming. Org. Agric. 2013, 4, 1-13. [CrossRef]

234. Marocco, A.; Gavazzi, C.; Pietri, A.; Tabaglio, V. On fumonisin incidence in monoculture maize under no-till, conventional tillage and two nitrogen fertilisation levels. J. Sci. Food Agric. 2008, 88, 1217-1221. [CrossRef]

235. Blandino, M.; Haidukowski, M.; Pascale, M.; Plizzari, L.; Scudellari, D.; Reyneri, A. Integrated strategies for the control of Fusarium head blight and deoxynivalenol contamination in winter wheat. Field Crops Res. 2012, 133, 139-149. [CrossRef]

236. Ono, E.Y.S.; Moreno, E.C.; Ono, M.A.; Rossi, C.N.; Saito, G.H.; Vizoni, É.; Sugiura, Y.; Hirooka, E.Y. Effect of cropping systems and crop successions on fumonisin levels in corn from Northern Paraná State, Brazil. Eur. J. Plant Pathol. 2011, 131, 653-660. [CrossRef]

237. Dill-Macky, R.; Jones, R.K. The effect of previous crop residues and tillage on Fusarium head blight of wheat. Plant Dis. 2000, 84, 71-76. [CrossRef] 
238. Del Ponte, E.M.; Shah, D.A.; Bergstrom, G.C. Spatial patterns of Fusarium head blight in New York wheat fields suggest role of airborne inoculum. Plant Health Prog. 2003, 10. [CrossRef]

239. Maldonado-Ramirez, S.L.; Schmale, D.G.; Shields, E.J.; Bergstrom, G.C. The relative abundance of viable spores of Gibberella zeae in the planetary boundary layer suggests the role of long-distance transport in regional epidemics of Fusarium head blight. Agric. For. Meteorol. 2005, 132, 20-27. [CrossRef]

240. Bateman, G.L.; Gutteridge, R.J.; Gherbawy, Y.; Thomsett, M.A.; Nicholson, P. Infection of stem bases and grains of winter wheat by Fusarium culmorum and F. graminearum and effects of tillage method and maize-stalk residues. Plant Pathol. 2007, 56, 604-615. [CrossRef]

241. Landschoot, S.; Audenaert, K.; Waegeman, W.; Pycke, B.; Bekaert, B.; de Baets, B.; Haesaert, G. Connection between primary Fusarium inoculum on gramineous weeds, crop residues and soil samples and the final population on wheat ears in Flanders, Belgium. Crop Prot. 2011, 30, 1297-1305. [CrossRef]

242. Schaafsma, A.W.; Tamburic-Ilincic, L.; Hooker, D.C. Effect of previous crop, tillage, field size, adjacent crop, and sampling direction on airborne propagules of Gibberella zeae/Fusarium graminearum, Fusarium head blight severity, and deoxynivalenol accumulation in winter wheat. Can. J. Plant Pathol. 2005, 27, 217-224. [CrossRef]

243. Buerstmayr, H.; Steiner, B.; Lemmens, M.; Ruckenbauer, P. Resistance to Fusarium head blight in winter wheat: Heritability and trait associations. Crop Sci. 2000, 40, 1012-1018. [CrossRef]

244. Buerstmayr, M.; Buerstmayr, H. Comparative mapping of quantitative trait loci for Fusarium head blight resistance and anther retention in the winter wheat population Capo $\times$ Arina. Theor. Appl. Genet. 2015, 128, 1519-1530. [CrossRef] [PubMed]

245. Yoshida, M.; Nakajima, T.; Arai, M.; Suzuki, F.; Tomimura, K. Effect of the timing of fungicide application on Fusarium head blight and mycotoxin accumulation in closed-flowering barley. Plant Dis. 2008, 92, 1164-1170. [CrossRef]

246. Nakajima, T.; Yoshida, M.; Tomimura, K. Effect of lodging on the level of mycotoxins in wheat, barley, and rice infected with the Fusarium graminearum species complex. J. Gen. Plant Pathol. 2008, 74, 289-295. [CrossRef]

247. Chetouhi, C.; Bonhomme, L.; Lecomte, P.; Cambon, F.; Merlino, M.; Biron, D.G.; Langin, T. A proteomics survey on wheat susceptibility to Fusarium head blight during grain development. Eur. J. Plant Pathol. 2015, 141, 407-418. [CrossRef] [PubMed]

248. Chetouhi, C.; Bonhomme, L.; Lasserre-Zuber, P.; Cambon, F.; Pelletier, S.; Renou, J.-P.; Langin, T. Transcriptome dynamics of a susceptible wheat upon Fusarium head blight reveals that molecular responses to Fusarium graminearum infection fit over the grain development processes. Funct. Integr. Genomics 2016, 16, 183-201. [CrossRef] [PubMed]

249. Bai, G.; Shaner, G. Scab of wheat: Prospects for control. Plant Dis. 1994, 78, 760-766.

250. Burt, C.; Steed, A.; Gosman, N.; Lemmens, M.; Bird, N.; Ramirez-Gonzalez, R.; Holdgate, S.; Nicholson, P. Mapping a Type 1 FHB resistance on chromosome 4AS of Triticum macha and deployment in combination with two Type 2 resistances. Theor. Appl. Genet. 2015, 128, 1725-1738. [CrossRef] [PubMed]

251. Buerstmayr, H.; Ban, T.; Anderson, J.A. QTL mapping and marker-assisted selection for Fusarium head blight resistance in wheat: A review. Plant Breed. 2009, 128,1-26. [CrossRef]

252. Lu, Q.; Lillemo, M.; Skinnes, H.; He, X.; Shi, J.; Ji, F.; Dong, Y.; Bjornstad, A. Anther extrusion and plant height are associated with Type I resistance to Fusarium head blight in bread wheat line 'Shanghai-3/Catbird'. Theor. Appl. Genet. 2013, 126, 317-334. [CrossRef] [PubMed]

253. He, X.; Singh, P.K.; Schlang, N.; Duveiller, E.; Dreisigacker, S.; Payne, T.; He, Z. Characterization of Chinese wheat germplasm for resistance to Fusarium head blight at CIMMYT, Mexico. Euphytica 2014, 195, 383-395. [CrossRef]

254. Kluger, B.; Bueschl, C.; Lemmens, M.; Michlmayr, H.; Malachova, A.; Koutnik, A.; Maloku, I.; Berthiller, F.; Adam, G.; Krska, R.; et al. Biotransformation of the mycotoxin deoxynivalenol in Fusarium resistant and susceptible near isogenic wheat lines. PLoS ONE 2015, 10, e0119656. [CrossRef] [PubMed]

255. Boutigny, A.-L.; Richard-Forget, F.; Barreau, C. Natural mechanisms for cereal resistance to the accumulation of Fusarium trichothecenes. Eur. J. Plant Pathol. 2008, 121, 411-423. [CrossRef]

256. Ji, F.; Wu, J.; Zhao, H.; Xu, J.; Shi, J. Relationship of deoxynivalenol content in grain, chaff, and straw with Fusarium head blight severity in wheat varieties with various levels of resistance. Toxins 2015, 7, 728-742. [CrossRef] [PubMed] 
257. Xiang, K.; Zhang, Z.M.; Reid, L.M.; Zhu, X.Y.; Yuan, G.S.; Pan, G.T. A meta-analysis of QTL associated with ear rot resistance in maize. Maydica 2010, 55, 281-290.

258. Martin, M.; Miedaner, T.; Dhillon, B.S.; Ufermann, U.; Kessel, B.; Ouzunova, M.; Schipprack, W.; Melchinger, A.E. Colocalization of QTL for Gibberella ear rot resistance and low mycotoxin contamination in early European maize. Crop Sci. 2011, 51, 1935-1945. [CrossRef]

259. Horne, D.W.; Eller, M.S.; Holland, J.B. Responses to recurrent index selection for reduced Fusarium ear rot and lodging and for increased yield in maize. Crop Sci. 2016, 56, 85-94. [CrossRef]

260. Blandino, M.; Reyneri, A. Effect of maize hybrid maturity and grain hardness on fumonisin and zearalenone contamination. Ital. J. Agron. 2008, 3, 107-117. [CrossRef]

261. Pietri, A.; Battilani, P.; Gualla, A.; Bertuzzi, T. Mycotoxin levels in maize produced in northern Italy in 2008 as influenced by growing location and FAO class of hybrid. World Mycotoxin J. 2012, 5, 409-418. [CrossRef]

262. Battilani, P.; Formenti, S.; Ramponi, C.; Rossi, V. Dynamic of water activity in maize hybrids is crucial for fumonisin contamination in kernels. J. Cereal Sci. 2011, 54, 467-472. [CrossRef]

263. Dall'Asta, C.; Falavigna, C.; Galaverna, G.; Battilani, P. Role of maize hybrids and their chemical composition in Fusarium infection and fumonisin production. J. Agric. Food Chem. 2012, 60, 3800-3808. [CrossRef] [PubMed]

264. Atanasova-Penichon, V.; Pons, S.; Pinson-Gadais, L.; Picot, A.; Marchegay, G.; Bonnin-Verdal, M.-N.; Ducos, C.; Barreau, C.; Roucolle, J.; Sehabiague, P. Chlorogenic acid and maize ear rot resistance: A dynamic study investigating Fusarium graminearum development, deoxynivalenol production, and phenolic acid accumulation. Mol. Plant. Microbe Interact. 2012, 25, 1605-1616. [CrossRef] [PubMed]

265. Bowers, E.; Hellmich, R.; Munkvold, G. Comparison of fumonisin contamination using HPLC and ELISA methods in Bt and near-isogenic maize hybrids infested with European corn borer or Western bean cutworm. J. Agric. Food Chem. 2014, 62, 6463-6472. [CrossRef] [PubMed]

266. Choo, T.M.; Martin, R.A.; Savard, M.E.; Blackwell, B. Effects of planting date and earliness on deoxynivalenol contamination in barley under natural epidemic conditions. Can. J. Plant Sci. 2014, 94, 1363-1371. [CrossRef]

267. Blandino, M.; Reyneri, A.; Vanara, F. Effect of sowing time on toxigenic fungal infection and mycotoxin contamination of maize kernels. J. Phytopathol. 2009, 157, 7-14. [CrossRef]

268. Tokatlidis, I.S.; Has, V.; Melidis, V.; Has, I.; Mylonas, I.; Evgenidis, G.; Copandean, A.; Ninou, E.; Fasoula, V.A. Maize hybrids less dependent on high plant densities improve resource-use efficiency in rainfed and irrigated conditions. Field Crops Res. 2011, 120, 345-351. [CrossRef]

269. Blandino, M.; Reyneri, A.; Vanara, F. Effect of plant density on toxigenic fungal infection and mycotoxin contamination of maize kernels. Field Crops Res. 2008, 106, 234-241. [CrossRef]

270. Postic, J.; Cosic, J.; Vrandecic, K.; Jurkovic, D.; Saleh, A.A.; Leslie, J.F. Diversity of Fusarium species isolated from weeds and plant debris in Croatia. J. Phytopathol. 2012, 160, 76-81. [CrossRef]

271. Mourelos, C.A.; Malbrán, I.; Balatti, P.A.; Ghiringhelli, P.D.; Lori, G.A. Gramineous and non-gramineous weed species as alternative hosts of Fusarium graminearum, causal agent of Fusarium head blight of wheat, in Argentina. Crop Prot. 2014, 65, 100-104. [CrossRef]

272. Teich, A.H.; Nelson, K. Survey of Fusarium head blight and possible effects of cultural practices in wheat fields in Lambton County in 1983. Can. Plant Dis. Surv. 1984, 64, 11-13.

273. Kremer, R.J.; Means, N.E. Glyphosate and glyphosate-resistant crop interactions with rhizosphere microorganisms. Eur. J. Agron. 2009, 31, 153-161. [CrossRef]

274. Duke, S.O.; Wedge, D.E.; Cerdeira, A.L.; Matallo, M.B. Interactions of synthetic herbicides with plant disease and microbial herbicides. In Novel Biotechnologies for Biocontrol Agent Enhancement and Management; Springer: Berlin, Germany, 2007; pp. 277-296.

275. Powell, J.R.; Swanton, C.J. A critique of studies evaluating glyphosate effects on diseases associated with Fusarium spp. Weed Res. 2008, 48, 307-318. [CrossRef]

276. Johal, G.S.; Huber, D.M. Glyphosate effects on diseases of plants. Eur. J. Agron. 2009, 31, 144-152. [CrossRef]

277. Fernandez, M.R.; Selles, F.; Gehl, D.; DePauw, R.M.; Zentner, R.P. Crop production factors associated with Fusarium head blight in spring wheat in eastern Saskatchewan. Crop Sci. 2005, 45, 1908-1916. [CrossRef]

278. Reddy, K.N.; Abbas, H.K.; Zablotowicz, R.M.; Abel, C.A.; Koger, C.H. Mycotoxin occurrence and Aspergillus flavus soil propagules in a corn and cotton glyphosate-resistant cropping systems. Food Addit. Contam. 2007, 24, 1367-1373. [CrossRef] [PubMed] 
279. Bérubé, M.-E.; Vanasse, A.; Rioux, S.; Bourget, N.; Dion, Y.; Tremblay, G. Effect of glyphosate on Fusarium head blight in wheat and barley under different soil tillages. Plant Dis. 2011, 96, 338-344. [CrossRef]

280. Gautam, P.; Dill-Macky, R. Impact of moisture, host genetics and Fusarium graminearum isolates on Fusarium head blight development and trichothecene accumulation in spring wheat. Mycotoxin Res. 2012, 28, 45-58. [CrossRef] [PubMed]

281. Wegulo, S.N.; Baenziger, P.S.; Hernandez Nopsa, J.; Bockus, W.W.; Hallen-Adams, H. Management of Fusarium head blight of wheat and barley. Crop Prot. 2015, 73, 100-107. [CrossRef]

282. Kharbikar, L.L.; Dickin, E.T.; Edwards, S.G. Impact of post-anthesis rainfall, fungicide and harvesting time on the concentration of deoxynivalenol and zearalenone in wheat. Food Addit. Contam. A 2015, 32, 2075-2085. [CrossRef] [PubMed]

283. Torelli, E.; Firrao, G.; Bianchi, G.; Saccardo, F.; Locci, R. The influence of local factors on the prediction of fumonisin contamination in maize. J. Sci. Food Agric. 2012, 92, 1808-1814. [CrossRef] [PubMed]

284. Ariño, A.; Herrera, M.; Juan, T.; Estopañan, G.; Carramiñana, J.J.; Rota, C.; Herrera, A. Influence of agricultural practices on the contamination of maize by fumonisin mycotoxins. J. Food Prot. 2009, 72, 898-902. [PubMed]

285. Heier, T.; Jain, S.K.; Kogel, K.-H.; Pons-Kühnemann, J. Influence of N-fertilization and fungicide strategies on Fusarium head blight severity and mycotoxin content in winter wheat. J. Phytopathol. 2005, 153, 551-557. [CrossRef]

286. Bernhoft, A.; Torp, M.; Clasen, P.-E.; Løes, A.-K.; Kristoffersen, A.B. Influence of agronomic and climatic factors on Fusarium infestation and mycotoxin contamination of cereals in Norway. Food Addit. Contam. A 2012, 29, 1129-1140. [CrossRef] [PubMed]

287. Blandino, M.; Reyneri, A.; Vanara, F. Influence of nitrogen fertilization on mycotoxin contamination of maize kernels. Crop Prot. 2008, 27, 222-230. [CrossRef]

288. Hajiboland, R. Effect of micronutrient deficiencies on plants stress responses. In Abiotic Stress Responses in Plants; Ahmad, P., Prasad, M.N.V., Eds.; Springer: New York, Ny, USA, 2012; pp. 283-329.

289. Huber, D.M.; Jones, J.B. The role of magnesium in plant disease. Plant Soil 2012, 368, 73-85. [CrossRef]

290. Miller, J.D.; Culley, J.; Fraser, K.; Hubbard, S.; Meloche, F.; Ouellet, T.; Lloyd Seaman, W.; Seifert, K.A.; Turkington, K.; Voldeng, H. Effect of tillage practice on Fusarium head blight of wheat. Can. J. Plant Pathol. 1998, 20, 95-103. [CrossRef]

291. Chen, G.; Hinds, J.; Zobel, E.; Rosario-Lebron, A.; Hooks, C.R.R. Evaluation of prophylactic sprays on pest abundance, foliar damage and yield in winter wheat. Int. J. Pest Manag. 2015, 61, 161-170. [CrossRef]

292. Bagga, P. Fusarium Head Blight (FHB) of wheat: Role of host resistance, wheat aphids, insecticide and strobilurin fungicide in disease control in Punjab, India. Cereal Res. Commun. 2008, 36, 667-670. [CrossRef]

293. Scarpino, V.; Reyneri, A.; Vanara, F.; Scopel, C.; Causin, R.; Blandino, M. Relationship between European Corn Borer injury, Fusarium proliferatum and F. subglutinans infection and moniliformin contamination in maize. Field Crops Res. 2015, 183, 69-78. [CrossRef]

294. Watrous, K.; Rice, K.; Fleischer, S.; Smiles, S. Evaluation of foliar insecticides for the control of Lepidopterans, 2014. Arthropod Manag. Tests 2015, 40, E73. [CrossRef]

295. Saladini, M.A.; Blandino, M.; Reyneri, A.; Alma, A. Impact of insecticide treatments on Ostrinia nubilalis (Hübner) (Lepidoptera: Crambidae) and their influence on the mycotoxin contamination of maize kernels. Pest Manag. Sci. 2008, 64, 1170-1178. [CrossRef] [PubMed]

296. Papst, C.; Utz, H.F.; Melchinger, A.E.; Eder, J.; Magg, T.; Klein, D.; Bohn, M. Mycotoxins produced by Fusarium spp. in isogenic Bt vs. non-Bt maize hybrids under European corn borer pressure. Agron. J. 2005, 97, 219-224.

297. D'Angelo, D.L.; Bradley, C.A.; Ames, K.A.; Willyerd, K.T.; Madden, L.V.; Paul, P.A. Efficacy of fungicide applications during and after anthesis against Fusarium head blight and deoxynivalenol in soft red winter wheat. Plant Dis. 2014, 98, 1387-1397. [CrossRef]

298. Ruske, R.E.; Gooding, M.J.; Jones, S.A. The effects of adding picoxystrobin, azoxystrobin and nitrogen to a triazole programme on disease control, flag leaf senescence, yield and grain quality of winter wheat. Crop Prot. 2003, 22, 975-987. [CrossRef]

299. Paul, P.A.; Lipps, P.E.; Hershman, D.E.; McMullen, M.P.; Draper, M.A.; Madden, L.V. Efficacy of triazole-based fungicides for Fusarium head blight and deoxynivalenol control in wheat: A multivariate meta-analysis. Phytopathology 2008, 98, 999-1011. [CrossRef] [PubMed] 
300. Ioos, R.; Belhadj, A.; Menez, M.; Faure, A. The effects of fungicides on Fusarium spp. and Microdochium nivale and their associated trichothecene mycotoxins in French naturally-infected cereal grains. Crop Prot. 2005, 24, 894-902. [CrossRef]

301. De Curtis, F.; De Cicco, V.; Haidukowski, M.; Pascale, M.; Somma, S.; Moretti, A. Effects of agrochemical treatments on the occurrence of Fusarium ear rot and fumonisin contamination of maize in Southern Italy. Field Crops Res. 2011, 123, 161-169. [CrossRef]

302. Willyerd, K.T.; Li, C.; Madden, L.V.; Bradley, C.A.; Bergstrom, G.C.; Sweets, L.E.; McMullen, M.; Ransom, J.K.; Grybauskas, A.; Osborne, L.; et al. Efficacy and stability of integrating fungicide and cultivar resistance to manage Fusarium Head Blight and deoxynivalenol in wheat. Plant Dis. 2012, 96, 957-967. [CrossRef]

303. Haidukowski, M.; Visconti, A.; Perrone, G.; Vanadia, S.; Pancaldi, D.; Covarelli, L.; Balestrazzi, R.; Pascale, M. Effect of prothioconazole-based fungicides on Fusarium head blight, grain yield and deoxynivalenol accumulation in wheat under field conditions. Phytopathol. Mediterr. 2012, 51, 236-246.

304. Scarpino, V.; Reyneri, A.; Sulyok, M.; Krska, R.; Blandino, M. Effect of fungicide application to control Fusarium head blight and 20 Fusarium and Alternaria mycotoxins in winter wheat (Triticum aestivum L.). World Mycotoxin J. 2015, 8, 499-510. [CrossRef]

305. Kokkonen, M.; Magan, N.; Medina, A. Comparative effects of fungicides and environmental factors on growth and T-2+ HT-2 toxin production by Fusarium sporotrichioides and Fusarium langsethiae strains on an oat-based matrix. World Mycotoxin J. 2014, 7, 177-186. [CrossRef]

306. Edwards, S.; Anderson, E. Impact of agronomy on HT-2 and T-2 toxin content of oats. Plant Breed. Seed Sci. 2011, 63, 49-57. [CrossRef]

307. Simpson, D.R.; Weston, G.E.; Turner, J.A.; Jennings, P.; Nicholson, P. Differential control of head blight pathogens of wheat by fungicides and consequences for mycotoxin contamination of grain. Eur. J. Plant Pathol. 2001, 107, 421-431. [CrossRef]

308. Pirgozliev, S.R.; Edwards, S.G.; Hare, M.C.; Jenkinson, P. Effect of dose rate of azoxystrobin and metconazole on the development of Fusarium head blight and the accumulation of deoxynivalenol (DON) in wheat grain. Eur. J. Plant Pathol. 2002, 108, 469-478. [CrossRef]

309. Audenaert, K.; Callewaert, E.; Höfte, M.; Saeger, S.D.; Haesaert, G. Hydrogen peroxide induced by the fungicide prothioconazole triggers deoxynivalenol (DON) production by Fusarium graminearum. BMC Microbiol. 2010, 10. [CrossRef] [PubMed]

310. Marín, P.; de Ory, A.; Cruz, A.; Magan, N.; González-Jaén, M.T. Potential effects of environmental conditions on the efficiency of the antifungal tebuconazole controlling Fusarium verticillioides and Fusarium proliferatum growth rate and fumonisin biosynthesis. Int. J. Food Microbiol. 2013, 165, 251-258. [CrossRef] [PubMed]

311. Luongo, L.; Galli, M.; Corazza, L.; Meekes, E.; Haas, L.D.; Van Der Plas, C.L.; Köhl, J. Potential of fungal antagonists for biocontrol of Fusarium spp. in wheat and maize through competition in crop debris. Biocontrol Sci. Technol. 2005, 15, 229-242. [CrossRef]

312. Chulze, S.N.; Palazzini, J.M.; Torres, A.M.; Barros, G.; Ponsone, M.L.; Geisen, R.; Schmidt-Heydt, M.; Köhl, J. Biological control as a strategy to reduce the impact of mycotoxins in peanuts, grapes and cereals in Argentina. Food Addit. Contam. A 2015, 32, 471-479. [CrossRef] [PubMed]

313. Pan, D.; Mionetto, A.; Tiscornia, S.; Bettucci, L. Endophytic bacteria from wheat grain as biocontrol agents of Fusarium graminearum and deoxynivalenol production in wheat. Mycotoxin Res. 2015, 31, 137-143. [CrossRef] [PubMed]

314. Mousa, W.K.; Shearer, C.R.; Limay-Rios, V.; Zhou, T.; Raizada, M.N. Bacterial endophytes from wild maize suppress Fusarium graminearum in modern maize and inhibit mycotoxin accumulation. Front. Plant Sci. 2015, 6. [CrossRef] [PubMed]

315. Aiyaz, M.; Divakara, S.T.; Nayaka, S.C.; Hariprasad, P.; Niranjana, S.R. Application of beneficial rhizospheric microbes for the mitigation of seed-borne mycotoxigenic fungal infection and mycotoxins in maize. Biocontrol Sci. Technol. 2015, 25, 1105-1119. [CrossRef]

316. Samsudin, N.I.p.; Magan, N. Efficacy of potential biocontrol agents for control of Fusarium verticillioides and fumonisin B1 under different environmental conditions. World Mycotoxin J. 2015, 9, 205-213. [CrossRef]

317. Matarese, F.; Sarrocco, S.; Gruber, S.; Seidl-Seiboth, V.; Vannacci, G. Biocontrol of Fusarium head blight: Interactions between Trichoderma and mycotoxigenic Fusarium. Microbiology 2012, 158, 98-106. [CrossRef] [PubMed] 
318. Palazzini, J.M.; Groenenboom-de Haas, B.H.; Torres, A.M.; Köhl, J.; Chulze, S.N. Biocontrol and population dynamics of Fusarium spp. on wheat stubble in Argentina. Plant Pathol. 2013, 62, 859-866. [CrossRef]

319. Ferrigo, D.; Raiola, A.; Rasera, R.; Causin, R. Trichoderma harzianum seed treatment controls Fusarium verticillioides colonization and fumonisin contamination in maize under field conditions. Crop Prot. 2014, 65, 51-56. [CrossRef]

320. Ferrigo, D.; Raiola, A.; Piccolo, E.; Scopel, C.; Causin, R. Trichoderma harzianum T22 induces in maize systemic resistance against Fusarium verticillioides. J. Plant Pathol. 2014, 96, 133-142.

321. Moya-Elizondo, E.A.; Jacobsen, B.J. Integrated management of Fusarium crown rot of wheat using fungicide seed treatment, cultivar resistance, and induction of systemic acquired resistance (SAR). Biol. Control 2016, 92, 153-163. [CrossRef]

322. Pani, G.; Scherm, B.; Azara, E.; Balmas, V.; Jahanshiri, Z.; Carta, P.; Fabbri, D.; Dettori, M.A.; Fadda, A.; Dessì, A.; et al. Natural and natural-like phenolic inhibitors of type B trichothecene in vitro production by the wheat (Triticum sp.) pathogen Fusarium culmorum. J. Agric. Food Chem. 2014, 62, 4969-4978. [CrossRef] [PubMed]

323. Gauthier, L.; Verdal, M.-N.; Marchegay, G.; Pinson-Gadais, L.; Ducos, C.; Richard-Forget, F.; Atanasova-Penichon, V. Fungal biotransformation of chlorogenic and caffeic acids by Fusarium graminearum: New insights in the contribution of phenolic acids to resistance to deoxynivalenol accumulation in cereals. Int. J. Food Microbiol. 2016, 221, 61-68. [CrossRef] [PubMed]

324. Ferrochio, L.; Cendoya, E.; Farnochi, M.C.; Massad, W.; Ramirez, M.L. Evaluation of ability of ferulic acid to control growth and fumonisin production of Fusarium verticillioides and Fusarium proliferatum on maize based media. Int. J. Food Microbiol. 2013, 167, 215-220. [CrossRef] [PubMed]

325. Roselló, J.; Sempere, F.; Sanz-Berzosa, I.; Chiralt, A.; Santamarina, M.P. Antifungal activity and potential use of essential oils against Fusarium culmorum and Fusarium verticillioides. J. Essent. Oil Bear. Plants 2015, 18, 359-367. [CrossRef]

326. Turek, C.; Stintzing, F.C. Stability of essential oils: A review. Compr. Rev. Food Sci. Food Saf. 2013, 12, 40-53. [CrossRef]

327. Kfoury, M.; Sahraoui, A.L.-H.; Bourdon, N.; Laruelle, F.; Fontaine, J.; Auezova, L.; Greige-Gerges, H.; Fourmentin, S. Solubility, photostability and antifungal activity of phenylpropanoids encapsulated in cyclodextrins. Food Chem. 2016, 196, 518-525. [CrossRef] [PubMed]

(C) 2016 by the authors; licensee MDPI, Basel, Switzerland. This article is an open access article distributed under the terms and conditions of the Creative Commons Attribution (CC-BY) license (http://creativecommons.org/licenses/by/4.0/). 